Zabytkoznawstwo i Konserwatorstwo LII (2021)

\title{
Badania techniki i technologii malarskiej cudami słynącej Piety z Czarnego Potoku (1649 r.)
}

\author{
ANNA BOROWSKA \\ niezależny konserwator zabytków, Kraków \\ e-mail: annabor@mp.pl \\ ORCID: 0000-0002-3296-6892
}

MARIA GORYL

Wydział Konserwacji i Restauracji Dzieł Sztuki, Akademia Sztuk Pięknych w Krakowie e-mail: mgoryl@asp.krakow.pl

ORCID: 0000-0001-8730-3423

MAtGORZATA WALCZAK

Wydział Konserwacji i Restauracji Dzieł Sztuki, Akademia Sztuk Pięknych w Krakowie e-mail: mwalczak@asp.krakow.pl

ORCID: 0000-0002-7808-1627

Keywords: Pieta, Our Lady of Sorrows, Mater Dolorosa, Czarny Potok, Matschius Ingenraen / Ingermann, XVII ${ }^{\text {th }}$ century painting, painting technique and technology, MOLAB FIXLAB PL, MA-XRF, SEM-EDS, FTIR

Słowa kluczowe: Pieta, Matka Boska Bolesna, Mater Dolorosa, Czarny Potok, Mateusz Ingerman, malarstwo XVII w., technika i technologia malarstwa, MOLAB FIXLAB PL, MA-XRF, SEM-EDS, FTIR

Abstract

Investigations of Painting's Technology and Techniques of the Miraculous Image of Pietà of Czarny Potok (1649)

As a part of the $3^{\text {rd }}$ edition of MOLAB/FIXLAB PL in 2019 a programme of examination of a panel painting depicting the miraculous image of Our Lady of Sorrows, known as the Pietà of Czarny Potok (1649) was carried out. The painting is attributed to an 
Antwerp painter, studying in Rome, Matthew Ingerman, who had settled in Lesser Poland in XVII c. Both sides of the painting were photographed in analytical lights (VIS, $\mathrm{Na}, \mathrm{UV}, \mathrm{IR}$ ) and then scanned using the X-ray macro-fluorescence method (MA-XRF), this resulted in acquiring legible maps of the elemental composition on its surface and a preliminary assessment of the pigments used by the artist as well as of the range of subsequent transformations - overpaintings. On the reverse, underneath a visible inscription in black, its original version equal in contents was revealed, with two additional letters of the name of the former parson of the church in Czarny Potok visible. Samples were taken from the key parts of the painting, to prepare cross sections which were subjected to an Energy Dispersive X-ray Spectroscopy on a Scanning Electron Microscope (SEM-EDS), which allowed for a detailed identification of the stratigraphy of individual parts of the painting and their composition. An interesting imprimitura was identified, as well as the use of: chalk, gypsum, lead white, minium, vermilion ochre, orpigment/realgar, azurite, smalt, ultramarine, bone black, vegetable black, umber and organic red lake in paint layers. The authenticity of the unique aureole around the head of Our Lady was confirmed during the research. The research was supplemented with the analysis of the binding media using the Fourier-transform infrared spectroscopy method (FTIR). It was established that the panel was coated with a chalk and glue primer, and the painting was created in tempera technique with colourful glazes.

\section{Abstrakt}

W ramach trzeciego naboru wniosków MOLAB/FIXLAB PL w 2019 r. zrealizowano program badań obrazu tablicowego z cudami słynącym wizerunkiem Matki Boskiej Bolesnej, tzw. Piety z Czarnego Potoku (1649 r.), której autorstwo przypisuje się antwerpskiemu malarzowi wykształconemu w Rzymie - Mateuszowi Ingermanowi, osiadłemu w Małopolsce w XVII w. Obraz został z obu stron sfotografowany w światłach analitycznych (VIS, Na, UV, IR), a następnie poddany skanowaniu metodą makrofluorescencji rentgenowskiej (MA-XRF), dzięki czemu uzyskano czytelne mapy rozkładu pierwiastków na jego powierzchni i wstępną ocenę użytych przez artystę pigmentów oraz zasięg późniejszych przekształceń. Na odwrociu, pod widniejącym napisem czernią, odnaleziono jego pierwotną wersję o zbieżnej treści, z dodatkowo widocznymi dwiema kolejnymi literami nazwiska dawnego proboszcza kościoła w Czarnym Potoku. Z kluczowych miejsc malowidła pobrano i przygotowano przekroje boczne, które poddano energodyspersyjnej analizie rentgenowskiej na skaningowym mikroskopie elektronowym z analizatorem EDS (SEM-EDS), co pozwoliło na szczegółowe rozpoznanie stratygrafii poszczególnych partii obiektu i ich składu. Stwierdzono występowanie na obrazie ciekawej imprimitury oraz użycie w warstwach malarskich: kredy, gipsu, bieli ołowiowej, minii, vermillionu, ochry, aurypigmentu/realgaru, glejty ołowiowej, azurytu, smalty, ultramaryny, czerni kostnej, roślinnej, umbry oraz laserunków organicznych, w tym kraplaku. W trakcie badań potwierdzono autentyczność wyjątkowej aureoli wokół głowy Matki Bożej. Badania uzupełniono analizą spoiw metodą spektroskopii adsorpcyjnej w podczerwieni (FTIR). Ustalono, że tablica pokryta jest zaprawą kredowo-klejową, a malowidło wykonano w technice białkowo-żywicznej. 
Cudowna Pieta z Czarnego Potoku jest jednym z najważniejszych obiektów kultowych czczonych od wieków na terenie Sądecczyzny. Obraz, namalowany w okresie kontrreformacji, mieści się w nurcie szeroko rozwiniętego kultu maryjnego skupionego na współuczestnictwie Marii w zbawczej męce Syna ${ }^{1}$. Obszerną pracę poświęcił mu i opublikował w 1999 roku ks. Władysław Szczerbak ${ }^{2}$, który przeanalizował dostępne materiały archiwalne i osadził dzieło w kontekście historycznym. Nadal jednak obraz nie został poddany pogłębionej analizie stylistyczno-formalnej, co może wynikać z nielicznych dla niego analogii w sztuce Małopolski. O ile bowiem wśród odbitek graficznych i przedstawień malarskich z XVII wieku można znaleźć bliższe lub dalsze analogie podjętego przez artystę tematu Piety, o tyle trudno wśród zachowanych dzieł odnaleźć identyczny sposób operowania pędzlem - manierę malarską charakterystyczną dla autora omawianego obrazu. W obecnym stanie zachowania nawet współautorstwo najbliższej mu analogii, Piety z Wielogłów, wzbudza wątpliwości.

Dokładne badania technologii i techniki wykonania dzieła sztuki, stanowiących wizytówkę autora, pozwalają często na zawężenie kręgu poszukiwań jego twórcy do autorów podobnie wykonanych dzieł. Niestety, dotychczas nie powstała kompleksowa baza danych technologicznych dla siedemnastowiecznego malarstwa Małopolski, a obrazy będące obiektem kultu rzadko opuszczają kościoły. Przygotowując się do prac konserwatorskich, koniecznych ze względu na postępujące zniszczenie dzieła, skorzystaliśmy z okazji i wykonując szczegółowe analizy zebraliśmy informacje technologiczne o jednym z najważniejszych obrazów tego terenu, licząc, że zgromadzona wiedza posłuży w przyszłości do dokładniejszego ustalenia autora i proweniencji obrazu.

Zaprezentowany w niniejszym tekście program badawczy został zrealizowany w ramach trzeciego naboru wniosków MOLAB/FIXLAB PL w 2019 roku, umożliwiającego bezpłatny dostęp do aparatury badawczej Konsorcjum E-RIHS.pl, polskiego konsorcjum założonego w celu prowadzenia badań zabytkowych obiektów metodami fizykochemicznymi. Koordynatorem projektu była dr Małgorzata Walczak, analizy MA-XRF i SEM-EDS wykonała dr Maria Goryl, a badania FTIR dr Łucja Rodzik-Czałka z Wydziału Konserwacji i Restauracji Dzieł Sztuki Akademii Sztuk Pięknych w Krakowie, którym pragnę

Bardzo ciekawie ten aspekt kultu maryjnego w dobie kontrreformacji przedstawia monografia Magdaleny Pielas, Matka Boska Bolesna (Kraków: Universitas, 2000).

Władysław Szczerbak, Sanktuarium Matki Boskiej Bolesnej w Czarnym Potoku. Studium historyczno-ikonograficzne (Tarnów: Mała Poligrafia Redemptorystów w Tuchowie, 1999). 
gorąco podziękować za zaangażowanie i troskliwą pomoc. Wyniki badań zaprezentowano podczas czwartego warsztatu informacyjnego oferty MOLAB/ FIXLAB PL, 6 czerwca 2019 roku w Toruniu.

\section{Opis obrazu}

\section{Badane dzieło (il. 1) przedstawia motyw Piety i ma kształt pionowego prostoką-} ta o wymiarach $116,3 \mathrm{~cm} \times 75,3 \mathrm{~cm}$. Obraz zajmuje centralne miejsce w ołtarzu głównym ${ }^{3}$ drewnianego kościoła pw. św. Marcina Biskupa w Czarnym Potoku ${ }^{4}$

3 Wpis do rejestru zabytków nr B-129-3V z 13 II 1970 r. Archiwum Małopolskiego Wojewódzkiego Konserwatora Zabytków, Delegatura w Nowym Sączu.

4 Parafia powstała prawdopodobnie w 2. połowie XIII w. z fundacji miejscowych rodów rycerskich. Z braku dokumentów pisanych niewiele wiemy o pierwszej świątyni, wzniesionej może równolegle z erygowaniem parafii. Następnie, być może w miejsce wcześniejszej świątyni, zbudowano kolejny drewniany kościół, o znanym i aktualnym do dziś wezwaniu św. Marcina, konsekrowany w 1449 r., co odnotowano w wizytacji kanonicznej z 1596 r. na podstawie napisu widocznego wtenczas na chórze muzycznym, chorus superior kościoła, zob. Archiwum Kurii Metropolitalnej w Krakowie (dalej: AKMK), Akta Wizytacji Kapitulnych (dalej: AWK), sygn. AVCap 5/1596, Acta visitationis exterioris decanatuum Boboviensis, Sandecensis et Novi Fori ad archidiaconatum Sandecensem pertinentium per Christophorum Kazimirski a. 1596 expeditae, 63; por. Szczerbak, Sanktuarium, 12. Konsekrował kościół bp sufragan Jerzy, franciszkanin. Tenże kościół wspominają rejestry świętopietrza i dziesięcin z XV w., a w „Liber beneficiorum” z lat 1470-1480 Jan Długosz podał, że stał tu drewniany kościół parafialny św. Marcina, zob. Jan Długosz, Liber beneficiorum Dioecesis Cracoviensis. Opera omnia, wyd. A[ndrzej] Przezdziecki, t. 8 (Cracoviae: Ex Typographia Kirchmaieriana, 1863-1864), 301. W dokumencie z 1608 r. zaznaczono natomiast, że świątynia jest maleńka: „ecclesia parvula”, zob. AKMK, AWK, sygn. AVCap 25/1608, Visitatio decanatus Sandecensis et Novi Fori externa per Joannem Januszowski a. 1608 expedita, 423. W XV i XVI w. tutejsze dobra należały do rodu Ryterskich herbu Topór, a potem Pielszów i Wielogłowskich. W Czarnym Potoku była karczma, folwark, a ok. 1596 r. utworzono szkołę parafialną. Wieś zamieszkiwało wtedy ok. 270 osób, a w XVIII w. ok. 400 osób (liczby te dotyczą mieszkańców, którzy na Wielkanoc przyjęli komunię św.). W 1728 r. rozpoczęła się budowa nowego, stojącego do dziś kościoła: modrzewiowy, jednonawowy, stanął w miejscu poprzedniego w 1755 r., za probostwa ks. Augustyna Kawatkiewicza z Biskupic - informuje o tym kronika parafialna, zob. Archiwum Parafialne w Czarnym Potoku, Liber Memorabilium ad Ecclesia Parochiali Czarnopotocensi et de iis quae in ea gesta sunt et evenire, in parennem memoriam, rps; por. Szczerbak, Sanktuarium, 13. W wizytacji z 1793 r. oprócz informacji, że kościół był drewniany i potrzebował nowego pokrycia, zanotowano, że został poświęcony 28 III 1766 r., zob. Archiwum Parafialne w Łącku, Liber visitationum in decanatu Łącensi confectus a. 1793 et 1794 per Michaelem Skoczniowski dec. For. Łącensem; por. Bolesław Kumor, „Archidiakonat sądecki. Opracowanie tekstów źródłowych do atlasu historycznego kościoła w Polsce," Archiwa, Biblioteki i Muzea Kościelne 8 (1964): 282, 298. Wygląd kościoła znamy z rysunku, który opublikował Alojzy Fridrich, Historie cudownych obrazów Najświętszej Maryi Panny $w$ Polsce, t. 2 (Kraków: Wydawnictwo Towarzystwa Jezusowego, 1904), 459; por. Szczerbak, Sanktuarium, fot. 2. W XX w. kościół poddano znacznym przekształceniom (dodano wieżę, kaplicę w transepcie, zlikwidowano babińce). 
(gmina Łącko), historycznej wsi ziemi sądeckiej5. Maria wyobrażona została prawie centralnie, w pozycji siedzącej (oś kompozycji obrazu przesunięto nieco w prawo), zwrócona frontalnie do widza i podtrzymująca dłońmi spoczywające na jej kolanach martwe ciało Syna. Odnosi się wrażenie, że naga postać Chrystusa unosi się lekko, nie stanowiąc ciężaru dla trzymającej go Matki. Zbawiciel przedstawiony został bardzo poprawnie anatomicznie, jako młody, dobrze zbudowany mężczyzna o wyraźnie zarysowanych mięśniach, nagi, jedynie na biodrach okryty białym, gęsto drapowanym perizonium. Jego bezwładnie zwisające nogi oraz lewa ręka prawie dotykają ziemi. Oprócz pięknie, ze znawstwem oddanej anatomii ciała, zwraca uwagę dbałość o szczegóły modelunku i światłocienia twarzy, zwłaszcza Marii, oraz detali włosów i zarostu Jezusa. Różnicując obie postaci, wyraźnie skontrastowano bladość martwego ciała mężczyzny z ciepłą karnacją żywej kobiety.

Maria odziana jest w szaty odbiegające nieco od kolorystycznych kanonów ikonograficznych. Jej głowę i ramiona okrywa mocno udrapowana brunatna chusta, spod której widać różową suknię. Część chusty, która okrywa zacienione, lewe ramię Marii, a następnie spływa aż do ziemi za opadającą ręką Chrystusa, ma fioletowobrunatny odcień. Z ramienia Marii spływa również obszerny ciemnobłękitny płaszcz, okrywający jej kolana i ścielący się na podłożu. Wysunięta na pierwszy plan duża, bardzo jasna postać Zbawiciela przedstawiona została horyzontalnie, ale zrównoważona nieco wertykalnie przez Jego zwisające kończyny, a przede wszystkim postać Matki Bożej, której głowę otacza ogromna, kolista aureola mająca kształt zachodzącego słońca. Składa się ona z kręgów: jasnożółtego, ciemnopomarańczowego i brązowoczerwonego. Postaci umiejscowiono w plenerze, a ostatnia konserwacja ujawniła szczegóły bardzo skąpej, trawiastej roślinności i skał, na których siedzi Maria. Całość kompozycji przedstawiona została na czarnym tle.

Temat Piety ${ }^{6}$, wywodzący się ze sceny Opłakiwania Chrystusa, stanowiącej jedno z przedstawień pasyjnych, był szeroko rozpowszechniony zarówno w rzeźbie, jak i w malarstwie europejskim już od średniowiecza. W dobie

5 Ślady najstarszego osadnictwa w okolicy pochodzą już z neolitu. W okresie wczesnośredniowiecznym rozwinęła się osada na tzw. Gródku, wzniesieniu górującym nad wsią od strony zachodniej. W trakcie budowy szkoły znaleziono w wykopach ozdoby ceramiczne i monety pochodzące z czasów rzymskich. Andrzej Żaki, „Wyniki wstępnych badań grodziska w Naszowicach, powiat Nowy Sącz," Wiadomości Archeologiczne 3 (1954): 234-251. Najstarsze źródła pisane dotyczące Czarnego Potoku pochodzą z początku XIV w.; zestawienie źródeł dla wsi Czarny Potok zob. Kumor, „Archidiakonat sądecki,” 297-298.

6 Pielas, Matka Boska Bolesna, 27, 54, 199. 
kontrreformacji, w nurcie tzw. doloryzmu, szczególnie chętnie przedstawiano wyizolowane postaci Bolejącej Matki podtrzymującej umęczonego Syna. Komponując Pietę, artysta najprawdopodobniej zaadaptował grafikę do zaprojektowania dzieła ${ }^{7}$ i choć nie znaleziono dotychczas identycznego $\mathrm{z}$ nią pierwowzoru, to wśród zachowanych do dziś odbitek są przedstawienia bardzo podobne w układzie ${ }^{8}$.

W omawianym dziele wyjątkowym elementem kompozycji jest nimb inspirowany widokiem zachodzącego słońca, co wprost zdaje się odnosić do niemieckiego określenia tematu Piety jako Vesperbild (Obrazu wieczornego), nawiązującego do wieczornych godzin, w których rozegrały się wydarzenia na Golgocie9. Prawdopodobną inspiracją do takiego zobrazowania nimbu Marii był obraz Matki Boskiej Kodeńskiej, wykradziony z papieskiej kaplicy w Rzymie przez księcia Mikołaja Sapiehę Pobożnego w 1629 roku (książę wraz z obrazem dotarł do Kodnia 15 września 1631 r. (10 $^{10}$, lub wizerunek lwowskiej Matki Bożej Łaskawej ${ }^{11}$, wsławiony za sprawą niedawnej (1648) zwycięskiej obrony Lwowa przed najazdem Chmielnickiego, którego nimb o pastelowych tęczowych barwach mógł być bezpośrednim wzorem dla powstałej w 1648 roku Piety z Wielogłów - najbliższej analogii omawianego przedstawienia, o czym w dalszych rozważaniach.

Czarne tło obrazu wskazuje na bezpośredni cytat z Ewangelii św. Łukasza: gdy Chrystus umierał, „mrok ogarnął całą ziemię aż do godziny dziewiątej. Słońce się zaćmiło" (Łk 23, 44-45) ${ }^{12}$. Ks. Szczerbak wiąże je ze wzrastającą w malarstwie małopolskim połowy XVII wieku popularnością tenebryzmu ${ }^{13}$,

7 O adaptacjach grafik, a także ich kompilacjach i repetycjach w malarstwie sztalugowym wyczerpująco Zygmunt Michalczyk, W lustrzanym odbiciu. Grafika europejska a malarstwo w Rzeczypospolitej w czasach nowożytnych ze szczególnym uwzględnieniem późnego baroku (Warszawa: Instytut Sztuki PAN, 2016), 139-164.

8 Warto w tym kontekście zwrócić uwagę na grafikę ( 175 x 127 mm) z 1596 r. autorstwa Hendricka Goltziusa (1558-1617), która przedstawia podobnie ujęty temat Piety (choć tu Maria ma spuszczoną głowę, zamknięte oczy i złożone dłonie, a w tle widać Golgotę), a nimb Matki Bożej tworzą okręgi o różnym gradiencie.Źródło: https://onlineonly.christies.com/s/old-master-works-paper-prints-drawings-under-5-000/hendrick-goltzius-1558-1617-45/63177, dostęp 25 września 2021.

9 Myśl teologiczną związaną z taką interpretacją przedstawienia nimbu Marii szerzej rozwija Szczerbak, Sanktuarium, 55-57.

10 https://opoka.org.pl/biblioteka/Z/ZP/opiekun201815-koden.html, dostęp 27 września 2021.

11 https://sanktuariapolskie.com.pl/2018/09/26/lubaczow-sanktuarium-matki-bozej-laskawej/, dostęp 27 września 2021.

12 Cyt. za: Biblia Tysiąclecia (Poznań: Pallotinum, 2003).

13 Szczerbak, Sanktuarium, 76. 
maniery stosowanej zarówno przez Caravaggia, jak i Rembrandta, znanych z zamiłowania do ciemnych teł. Przeprowadzone badania technologii malarskiej dzieła wykazały jednak odmienny od klasycznej maniera tenebrosa sposób tworzenia małopolskiego malowidła, w tym zwłaszcza brak ciemnego, bolusowego tła, będącego podstawą budowania ostrego światłocienia (chiariscuro), co oznacza de facto, że autor obrazu nie zastosował tej metody.

\section{Historia obrazu i jego kultu}

Dotychczas nie odnaleziono żadnych źródeł pisanych informujących bezpośrednio o pochodzeniu i autorze cudownego wizerunku Matki Bożej Bolesnej. Klucz do datowania i atrybucji znajdujemy natomiast w samym dziele. W górnej szpondze obrazu wycięta jest data 1649, odnosząca się do czasu jego powstania. Z kolei badania technologiczne wykazały, że inicjały M.I. w lewym dolnym rogu należą do warstwy pierwotnej malowidła i zostawił je autor obrazu, a nie późniejszy jego renowator (namalowano go czystym vermilionem). Biorąc pod uwagę uzyskane wyniki badań, można z dużą dozą prawdopodobieństwa wysunąć tezę, że Pietę namalował Mateusz Ingerman, notowany też jako Mattfchus / Matschius Ingenraen / Ingermann / Inderlandczyk ${ }^{14}$.

Malarz ten, urodzony w Antwerpii, jak wielu współczesnych mu adeptów sztuki z Niderlandów studiował malarstwo w Rzymie ${ }^{15}$, gdzie zauważył go

14 Takie autorstwo obrazu sugeruje Szczerbak, Sanktuarium, 89-90, opierając się na wcześniejszych opracowaniach źródeł pisanych, na podstawie których wyodrębniono zaledwie dwóch artystów o pasujących inicjałach.

15 Wśród młodych twórców z krajów północnych modne stało się w tym czasie swoiste pielgrzymowanie do Italii i studiowanie tamtejszej sztuki. W 1604 r. Karel van Mander, flamandzki pisarz i malarz, wydał w Haarlemie Het Schilder-Boeck, bardzo dobrze przyjętą i sprzedającą się książkę o malarstwie, w której zachęcał niderlandzkich artystów do podróżowania do Włoch: „Mocno ponaglam cię do podróży, nie lękaj się, że zbłądzisz, gdyż Rzym jest miastem, które ponad wszystkie inne, może uczynić podróż artysty owocną, będąc stolicą szkół Malarstwa," Karel van Mander, Den Grondt der edel vry schilderkonst (Haarlem: Passchier Wesbusch, 1604), ks. I, cyt. w tłum. własnym za: Erin Elizabeth Downey, „The Bentveughels: Networking and Agency in the Seicento Roman Art Market" (rozprawa doktorska, Temple University, 2015), http://www.digital.library.temple.edu, dostęp 20 kwietnia 2021. Pełny tekst i faksymile książki van Mandera zob. Karel van Mander, Het schilder-boeck (facsimile van de eerste uitgave, Haarlem 1604, Utrecht: Davaco Publishers, 1969), http://www.dbnl. org/tekst/mand001schi01_01/colofon.htm. Erin Downey dogłębnie zanalizowała społeczność niderlandzkich twórców w Wiecznym Mieście, tworzących w latach 1620-1720 prężnie działające stowarzyszenie wspierających się nawzajem artystów imigrantów. Por. Élinor Myara Kelif, 'Flemish Artists' Training Voyages in Italy.' Encyclopédie pour une histoire numérique de l'Europe, https://ehne.fr/en/node/12514, dostęp 20 kwietnia 2021. 
Stanisław Lubomirski, wojewoda krakowski. Na jego zlecenie Ingerman wykonał między innymi wielkoformatowe obrazy do kościoła Karmelitów w Nowym Wiśniczu ${ }^{16}$ (podobno wywiezione do Wiednia w XIX wieku po kasacie klasztoru). Antwerpczyk w latach 1639-1641 pracował jako nadworny malarz, serwitor Lubomirskiego, portretując jego syna Aleksandra, co potwierdza zachowany inwentarz galerii wiśnickiej ${ }^{17}$. W 1641 roku artysta uzyskał nawet prawo miejskie w Krakowie jako „Comitis in Wisnic palatini Crac. Servitor” ${ }^{18}$.

Jedyny zachowany do dziś obraz przypisywany (wciąż ze znakiem zapytania) temu autorowi, czyli Ostatniq Wieczerzę pochodzącą z ołtarza bocznego dawnego kościoła Karmelitów Bosych w Nowym Wiśniczu, oglądać można w Muzeum Narodowym w Krakowie na ekspozycji w Pałacu Erazma Ciołka ${ }^{19}$. Jest to co prawda obraz na podobraziu płóciennym, lecz można zauważyć pewne podobieństwo stylu i techniki malarskiej obu przedstawień. Chcąc potwierdzić wspólną atrybucję obu obrazów, należałoby - niezależnie od studiów porównawczych stylu malarskiego - przeprowadzić również dla Ostatniej Wieczerzy analizy technologiczne, analogiczne do prezentowanych w niniejszym artykule.

16 Por. Benginus Józef Wanat OCD, „Architektura i wyposażenie kościoła i klasztoru Karmelitów Bosych w Wiśniczu," Folia Historica Cracoviensia 19 (2013): 128, za: Biblioteka Zakładu Narodowego im. Ossolińskich we Wrocławiu, rkps 1871/I, Relatio fundationis conventus visnicensis Salvatoris Carmelitarum Discalceatorum cum annalibus ejusdem monasterii 1624-1719 (dalej: Kronika klasztoru), k. 15v.

17 Szczerbak, Sanktuarium, 90; za: Władysław Tomkiewicz, Z dziejów polskiego mecenatu artystycznego w wieku XVII (Wrocław: Wydawnictwo Zakładu Narodowego im. Ossolińskich, 1952).

18 Archiwum Narodowe w Krakowie, Akta Miasta Krakowa, sygn. 29/33/0/1.21/1427, Cathalogus civium Cracoviensium secundi ordinis..., daty: 1634-1668, skan 34/100, https://www. szukajwarchiwach.gov.pl/jednostka/-/jednostka/5638751?_Jednostka_delta=20\&_Jednostka_resetCur=false\&_Jednostka_cur=3, dostęp 26 lipca 2021. Por. Stanisław Tomkowicz, Przyczynki do historyi kultury Krakowa w pierwszej poł. XVII w. (Lwów: Nakładem Towarzystwa dla Popierania Nauki Polskiej, 1912), 158; Elżbieta Kraińska, „Materiały źródłowe do malarstwa renesansowego w Małopolsce historycznej (1500-1650)," Sprawozdania z Posiedzeń Komisji PAN 1 (1962): 207; Elżbieta Kraińska, „Materiały archiwalne do historii małopolskiego malarstwa renesansowego (1500-1650)," Folia Historiae Artium 7 (1965): 98, 100, poz. 23; Słownik artystów polskich i obcych $w$ Polsce działających, t. 3 (Wrocław-Warszawa-KrakówGdańsk: PAN, 1979), 146; Piotr S. Szlezynger, Dawny kościół Karmelitów Bosych $w$ Wiśniczu (Bochnia-Nowy Wiśnicz: Stowarzyszenie Bochniaków i Miłośników Ziemi Bocheńskiej / Towarzystwo Miłośników Wiśnicza, 2009), 8.

19 Por. Szlezynger, Dawny kościót, 16. 
Dotychczasowi badacze dziejów Piety nie byli pewni, czy pierwotnie obraz przeznaczony był do kościoła ${ }^{20}$, czy też służył prywatnej dewocji w dworze fundatora, o którym pamięć szybko zaginęła. Już bowiem po kilkudziesięciu latach, w 1727 roku ks. Tomasz Włoszkiewicz przystępując do spisywania regularnej księgi łask Matki Bożej Czarnopotockiej pod tytułem „Gutta Maris gratianum Mariae...” stwierdził: „z kąd się ten naydroższy Kleynot na pociechę wszystkim Parafianom w Czarnym Potoku dostał, doścignąć mi nie można" ${ }^{21}$. Ks. Szczerbak zapewne słusznie przypisał fundację obrazu Wielogłowskim (jako najbardziej prawdopodobnego dobrodzieja wskazał Stefana Wielogłowskiego), kolatorów kościoła w Czarnym Potoku, którzy po śmierci swego przodka Sebastiana Wielogłowskiego, zagorzałego arianina, mogli ufundować obraz jako akt ekspiacji za jego grzechy i przewinienia wobec Kościoła ${ }^{22}$.

Fundacja Wielogłowskich zdaje się najpewniejsza, zwłaszcza że bezpośrednią analogię do Piety Czarnopotockiej stanowi obraz znajdujący się w ołtarzu bocznym kościoła w Wielogłowach koło Nowego Sącza, łudząco

20 Pierwsze akta wizytacyjne wzmiankujące obraz Piety zachowały się z 1728 r., odnotowano wtedy, że w głównym ołtarzu „Imum maius in quo est imago gratiosa B. V. M. Dolorosae”, zob. AKMK, AWK, sygn. AVCap 60/1728, Visitatio interna et externa Officialatus Sandecensis per Josephum de Zakliczyn Jordan a. 1723-1728 peracta, nr 60, 206; por. Szczerbak, Sanktuarium, 74. Na pewno łaskami słynący obraz Matki Bożej Bolesnej znajdował się w $1793 \mathrm{r}$. w wielkim ołtarzu kościoła parafialnego, zob. Archiwum Parafialne w Łącku, Liber visitationum in decanatu Łącensi confectus a. 1793 et 1794 per Michaelem Skoczniowski dec. For. Łącensem; por. Kumor, „Archidiakonat sądecki,” 298.

21 Zob. Archiwum Parafialne w Czarnym Potoku, Gutta Maris gratianum Mariae Etiam In Nigram Vallem Copioso Stillamine Cadens. Łaski Cudowne Skarby Pociech rozmaitych dobrodzieystwa prawie codzienne: od Nayboleśnieyszey Matki Jezusowey Przenayświentszey Maryi Panny w Obrazie iey Czarnopotockim doznane y odebrane. A przez Xiędza Tomasza Franciszka Włoszkiewicza Plebana Czarnopotockiego w fascuł zebrane y zkompendyowane Roku Pańskiego 1727. Piety dotyczą liczne wpisy w księdze i jej kontynuacji, najwcześniejszy z 1678 r., ostatnie z lat 20. XX w. W zapisanych podziękowaniach i prośbach utrwalono świadectwa otrzymanych łask i głęboką wiarę we wstawiennictwo Matki Bożej. Relacje podkreślają, że większość spisanych cudów nastąpiła w trakcie mszy św. w czasie podniesienia, a wierni przystępowali do spowiedzi i komunii św., by z czystym sercem prosić o miłosierdzie i łaskę. Ks. Zygmunt Miętus, proboszcz parafii w Czarnym Potoku w latach 1896-1910, zebrał i uporządkował zapisy łask i cudów, nadając im tytuł: „Zbiór łask cudownych doznanych od Najboleśniejszej Matki Jezusowej Przenajświętszej Maryi Panny w obrazie Jej łaskami słynącym w Czarnym Potoku”. Dziś w parafii prowadzona jest kronika, w której umieszczane są prośby i podziękowania Matce Bożej. Por. Anna Gąsior, Piotr Łabuda, i Janusz Królikowski, Współczująca Matka. Z historii Sanktuarium Matki Bożej Bolesnej w Czarnym Potoku (Tarnów: Wydawnictwo Diecezji Tarnowskiej Biblos, 2008).

22 Szczerbak, Sanktuarium, 26, 27, 65-67, 86-88. 
podobny ${ }^{23}$ (il. 2), datowany na 1648 rok dzięki umieszczonemu pod nim napisowi. Obok namalowane są należące do fundatorów herby Starykoń i Szreniawa. Idąc tropem powiązań obu obrazów, ks. Szczerbak zapewne słusznie łączył fundację wizerunku czarnopotockiego z rodem Wielogłowskich, związanych wtenczas z obiema miejscowościami ${ }^{24}$. W ołtarzu w Wielogłowach znajduje się aż siedem obrazów spójnych stylowo, wykonanych przez jeden warsztat. W tymże kościele w bliźniaczym ołtarzu bocznym umieszczono, oprócz centralnego wizerunku św. Anny, kolejnych sześć obrazów, co łącznie składa się na pokaźny zespół malowideł dających podstawę do dalszych badań warsztatu ich twórcy, którym ewentualnie mógł być Mateusz Ingerman (Mattfchus / Matschius Ingenraen / Ingermann).

Co ciekawe, oprócz podobnej kompozycji i kolorystyki, obie bliźniacze Piety wykazują też podobne zniszczenia warstw malarskich w postaci pęcherzykowatych odspojeń. Przy bliższych oględzinach obrazy różnią się sposobem malowania i modelowania karnacji; ks. Szczerbak wysuwa nawet przypuszczenie o odmiennym autorstwie obu dzieł, uważając, że po wykonaniu wielogłowskiej Piety fundatorzy poszukali lepszego malarza, który opierając się na takim samym wzorze namalował dla nich kolejny wizerunek ${ }^{25}$. Uważam, ze względu na obecny stan zachowania, że nie można wykluczyć obecności znaczniejszych przemalowań na obrazie z Wielogłów, które w istotnym stopniu wpływają na zaburzenie oceny jakości jego wykonania. Pewne jest natomiast, że mimo niewątpliwego podobieństwa obu wizerunków, jedynie Pieta Czarnopotocka uznana została za „Łaskami słynącą”26.

Historia czci Matki Bożej Bolesnej w Czarnym Potoku sięga połowy XV wieku. Przypuszczalnie przy budowie drugiej z kolei świątyni został do niej

${ }^{23}$ Po realizacji programu badawczego Piety Czarnopotockiej główna autorka niniejszego artykułu starała się, z dużym poparciem przedstawicieli Delegatury Wojewódzkiego Urzędu Ochrony Zabytków w Nowym Sączu, pozyskać do badań porównawczych Pietę z Wielogłów. Niestety, po oględzinach dokonanych przez jego konserwatorkę, p. Karolinę Kwiatkowską-Gawlik, okazało się niemożliwe wyjęcie obrazu bez demontażu całości struktury nastawy. Tym samym projekt technologicznych badań porównawczych został odsunięty w czasie.

24 Szczerbak, Sanktuarium, 80-88.

25 Szczerbak, Sanktuarium, 89-91.

26 Intensywnie kult Matki Bożej od 1867 r. szerzyło miejscowe bractwo różańcowe, liczące wtenczas aż tysiąc osób. Do dziś szczególnym wyrazem czci otaczającej Pietę z Czarnego Potoku są rzesze pielgrzymów, gromadzące się w czasie dwóch dorocznych odpustów: w piątek przed Niedzielą Palmową i w niedzielę po 15 września. W każdą środę odprawiana jest w sanktuarium nowenna do Matki Bożej Bolesnej, podczas której nadal przedstawiane są prośby, łaski i dziękczynienia. Szeroko o kulcie MB Czarnopotockiej Piotr Mamak, Kult Matki Boskiej Bolesnej w Czarnym Potoku (Tuchów: Mała Poligrafia Redemptorystów, 1999). 
ufundowany główny ołtarz - gotycki tryptyk z centralnym obrazem Opłakiwania Chrystusa ${ }^{27}$, zwanym w aktach wizytacji Zdjęciem z Krzyża („Altare maius / Structuram habet planam, antiquam, cum depositione Christi do Cruce” $)^{28}$, obecnie w Muzeum Diecezjalnym w Tarnowie. Być może pobliscy starosądeccy franciszkanie ${ }^{29}$ zapoczątkowali tam nabożeństwo do Męki Pańskiej, będąc szczególnymi głosicielami jej kultu i współcierpienia Matki Chrystusa.

Powstały w 1649 roku wizerunek Matki Boskiej Bolesnej szybko zasłynął łaskami, a pierwsza wiadomość o dokonanym przy nim cudzie - uzdrowieniu Jędrzeja Szwarcenberga, syna stolnika wołyńskiego - pochodzi już z 1678 roku $^{30}$. W podzięce rodzice złożyli wotum trzynastu grzywien srebra na korony i sukienki, o czym później wspominał na podstawie relacji żyjących jeszcze naocznych świadków ks. Tomasz Włoszkiewicz w księdze „Gutta Maris”: „pomieniona J[ejmość] Pani Stolnikowa dała srebra, złota na korony do Obrazu y ta Sukienka w trzynastu Grzywien srebra z szkatuły Ich Mościów spuścizna, o tym świadczy Gromada Czarni Potocka y insi parafianie" ${ }^{\text {"1 }}$. Nie wiadomo, czy sukienka od razu przykryła obraz, czy też ofiarowane srebro zostało wykorzystane w późniejszym czasie. Prawdopodobnie do jej nałożenia odnosiła się łacińska inskrypcja na rewersie obrazu, głosząca (w tłumaczeniu): „W roku 1714 obraz ten został ozdobiony sukienką srebrną na polecenie Ks. Michała Feliksińskiego", chociaż trudno dziś dociec, czy chodziło o następną koszulkę, czy o tak późną realizację zlecenia ofiarodawcy. Niewątpliwie jednak szybko, w podzięce za wysłuchane prośby, pojawiły się przy obrazie inne wota. Obecność rzeczonej srebrnej sukienki została potwierdzona w tekście wizytacji z 1728 roku, gdzie wyliczając kosztowności

27 Michał Walicki, Malarstwo polskie: gotyk, renesans, wczesny manieryzm (Warszawa: Auriga / Oficyna Wydawnicza w Warszawie, 1961), il. 31-34; Jerzy Gadomski, „Związki Mistrza ‘Opłakiwania’ z Chomranic z twórczością Roberta Campin,” Sprawozdania z Posiedzeń Komisji Naukowych Oddziału PAN w Krakowie 15, z. 1 (1971): 143-145; Jerzy Gadomski, Gotyckie malarstwo tablicowe Małopolski 1420-1470 (Warszawa: PWN, 1981), 96; Jerzy Gadomski, „Malarstwo tablicowe w Małopolsce,” w Malarstwo gotyckie w Polsce, t. 1, red. Adam S. Labuda i Krystyna Secomska (Warszawa: Wydawnictwo DiG, 2004), 266, il. 411-413.

28 AKMK, AWK, sygn. AVCap 5/1596, Acta visitationis, 64; AKMK, AWK, sygn. AVCap 5/1608, Visitatio, 423. Por. Szczerbak, Sanktuarium, 33.

29 W pobliskim Starym Sączu był wtenczas męski klasztor Franciszkanów, skasowany przez rząd austriacki w 1815 r., oraz funkcjonujący do dziś klasztor Klarysek.

30 Archiwum Parafialne w Czarnym Potoku, Gutta Maris, 24.

31 Archiwum Parafialne w Czarnym Potoku, Gutta Maris, 25. 
w kościele odnotowano kolejno: „Koron dwie, Vota trzy, Votum duże na obrazie Dolorosae B. V. Mariae" ${ }^{2}$.

Dziś bezpośrednio na tablicy znajdują się dwa wota: korona Matki Bożej i korona cierniowa Chrystusa, które Jan Paweł II poświęcił w Krakowie podczas pielgrzymki w 1997 roku, a 12 września 1999 roku biskup tarnowski ks. Wiktor Skworc uroczyście ukoronował nimi obraz. Zaprojektował je ks. Tadeusz Bukowski (były dyrektor Muzeum Diecezjalnego w Tarnowie), tworząc koronę Marii ze splecionych cierni i ostów, ze złota inkrustowanego kryształem górskim w formie krzyża i pięcioma rubinami, symbolizującymi rany Chrystusa ${ }^{33}$.

W dwadzieścia lat po koronacji, przed świętowaniem jej rocznicy, Pietę przekazano do konserwacji w związku z widocznymi postępującymi odspojeniami warstwy malarskiej i zaprawy. Nadarzyła się zatem niepowtarzalna okazja przeprowadzenia nowoczesnych badań fizykochemicznych dla określenia praktyki warsztatowej jej autora. Mimo wielkiego znaczenia Piety z Czarnego Potoku dla wiernych całej Sądecczyzny oraz jej niewątpliwej wartości artystycznej, obraz ten nigdy wcześniej nie został gruntownie przebadany, a w czasie poprzednich konserwacji skupiono się jedynie na pracach restauratorskich.

Stanisław Tomkowicz, opisując 1 sierpnia 1895 roku kościół w Czarnym Potoku ${ }^{34}$, zanotował: „W w.[ielkim] ołtarzu Pieta malowana na drzewie, o tle złotem, dobrego układu i rysunku, prawdopodobnie z XVI w., lecz bardzo przemalowana" ${ }^{35}$. Zastanawiająca i niepokojąca jest uwaga badacza dotycząca innego tła, gdyż trudno sobie wyobrazić ten manierystyczny obraz z archaicznym, złoconym tłem. Być może Tomkowicz widział jeszcze przykrywającą wizerunek koszulkę, która zaginęła, obecne zaś tło było ewidentnie przemalowane, należało więc dokładnie skontrolować tę partię dzieła.

Z zachowanych przekazów i dokumentacji wynika, że Pieta była kilkakrotnie poddawana konserwacji. W 1950 roku wykonał ją prof. Marian Słonecki (nie znaleziono żadnych informacji o zakresie zrealizowanych prac). W 1971

32 Por. przyp. 10.

33 Franciszek Pulit, „Historia obrazów - 'Opłakiwania Chrystusa' i 'Matki Boskiej Bolesnej' w Czarnym Potoku," Rocznik Sądecki 28 (2000): 34, 47.

34 Piotr Łopatkiewicz i Tadeusz Łopatkiewicz, Stanisława Tomkowicza Inwentarz zabytków powiatu sądeckiego (Kraków: Wydawnictwo MNK, 2007), 308, 309.

35 Łopatkiewicz i Łopatkiewicz, Inwentarz, 46. 
roku konserwacją zajmował się Zbigniew Jaskowskiji ${ }^{36}$, który miał usunąć z obrazu wszystkie przemalowania i odsłonić oryginalną warstwę malarską z połowy XVII wieku (taki lakoniczny przekaz zawiera skąpa dokumentacja prac). Ostatnia „renowacja”, przeprowadzona przez nieznanego konserwatora prawdopodobnie w 1999 roku przed koronacją obrazu, była powierzchowna i polegała głównie na nałożeniu retuszy bezpośrednio w ubytkach warstwy malarskiej, na zaprawie i pokrywającym ją podmalowaniu (imprimiturze) (być może te zabiegi wykonała, obok zasadniczych swych prac przy nastawie ołtarza głównego, Agata Osolińska, co nie zostało odnotowane w dokumentacji ${ }^{37}$ ).

\section{Metodyka badań}

Jak już wspomniano, przed przystąpieniem do prac konserwatorskich, w ramach trzeciego naboru wniosków MOLAB/FIXLAB PL w 2019 roku zrealizowano projekt badawczy, którego głównym celem było szczegółowe rozpoznanie technologii i techniki wykonania cudownej Piety z Czarnego Potoku. Ogromne znaczenie miało dokładne określenie stratygrafii obiektu i chronologii jego warstw. Zachodziła uzasadniona obawa, że wizerunek jest w wielu miejscach przemalowany, przez co utracił swój pierwotny charakter i kluczowe było ustalenie, które warstwy należy usunąć, nie niszcząc oryginału.

W celu jak najlepszego określenia technologii obiektu oraz zdiagnozowania jego przekształceń, przy użyciu zarazem metod wymagających pobrania jak najmniejszej ilości materiału, obraz został z obu stron sfotografowany w świetle VIS, UV, IR i sodowym (fotografie wykonał Paweł Gąsior), a następnie poddany skanowaniu metodą makrofluorescencji rentgenowskiej XRF, co pokazało rozkład pierwiastków na całej jego powierzchni i uwidoczniło przemalowania. Badania wykonała dr Maria Goryl na instrumencie M6 JetStream produkcji Bruker Nano $\mathrm{GmbH}$ w Berlinie ${ }^{38} \mathrm{z}$ oprogramowaniem fabrycznym, stosując parametry podane w tabeli 1 . Średnica plamki pomiarowej wynosiła $630 \mu \mathrm{m}$, a odległość między środkami plamek $390 \mu \mathrm{m}$. Obraz podzielono poprzecznie na dwa obszary, dla których pomiar trwał po siedemnaście godzin.

36 Zbigniew Jaskowski, „Dokumentacja techniczno-robocza z konserwacji obrazu na desce 'Pieta'” (dokumentacja konserwatorska, Kraków 1971, Archiwum WUOZ w Nowym Sączu, nr inw. 85). Jaskowski był absolwentem wydziału konserwacji ASP w Krakowie, a równocześnie z powodzeniem rozwijał karierę piłkarską. Por. http://www.historiawisly.pl

37 Agata Osolińska, „Dokumentacja prac przy ołtarzu” (dokumentacja konserwatorska, [brak miejscowości] 1999, Archiwum WUOZ w Nowym Sączu, nr inw. 5065).

38 http://www.bruker.com 
Tabela 1. Makrofluorescencja rentgenowska (Makro XRF). Parametry instrumentu M6 JetStream produkcji Bruker Nano GmbH w Berlinie z oprogramowaniem fabrycznym

\begin{tabular}{|l|l|}
\hline Mapping parameters & 1902 pixel \\
\hline Width: & $741.81 \mathrm{~mm}$ \\
\hline & 1503 pixel \\
\hline Height: & $586.038 \mathrm{~mm}$ \\
\hline & $390 \mu \mathrm{m}$ \\
\hline Pixel Size: & 2858706 pixel \\
\hline Total number of pixel: & \multicolumn{1}{|l|}{} \\
\hline Acquisition parameters & 1 \\
\hline Frame count: & $23 \mathrm{~ms} / \mathrm{pixel}$ \\
\hline Pixel time: & $16: 47 \mathrm{~h}$ \\
\hline Measure time: & $22: 03 \mathrm{~h}$ \\
\hline Overall time: & $17.0 \mathrm{~mm} / \mathrm{s}$ \\
\hline Stage speed: & $-333.626 ; 334.344 ; 76.513 \mathrm{~mm}$ \\
\hline Stage position $(\mathrm{X}, \mathrm{Y}, \mathrm{Z}):$ & \\
\hline Tube parameter & $50 \mathrm{kV}$ \\
\hline High voltage: & $199 \mu \mathrm{A}$ \\
\hline Anode current: & Empty \\
\hline Filter: & Lens \\
\hline Optic: & 630 \\
\hline SpotSize: & Air $1000 \mathrm{mbar}$ \\
\hline Chamber at: & $---1 / \mathrm{min}$ \\
\hline & $\mathrm{Rh}$ \\
\hline Anode: & 1 \\
\hline Detector parameters & $130000 \mathrm{cps}$ \\
\hline Selected detectors: & \\
\hline Max. pulse throughput: & \\
\hline & \\
\hline
\end{tabular}

Źródło: opracowanie własne.

Analizując mapy rozkładu pierwiastków na obiekcie wytypowano miejsca kluczowe dla dalszych badań, a następnie pobrano z nich osiem próbek, które zostały zatopione w żywicy epoksydowej i wyszlifowane w celu otrzymania przekrojów poprzecznych. Przekroje sfotografowano w świetle VIS odwróconym mikroskopem optycznym firmy Zeiss model NEOPHOT 32 oraz we fluorescencji wzbudzanej UV za pomocą mikroskopu optycznego Nikon Eclipse 80i, a następnie poddano je energodyspersyjnej analizie rentgenowskiej na skaningowym mikroskopie elektronowym z analizatorem EDS. 
Badania składu chemicznego wykonano za pomocą przystawki EDS (IXRF Systems) do mikroskopu elektronowego SEM (JEOL 5500 LV). Podczas analizy napięcie przyspieszające wynosiło $20 \mathrm{kV}$, a odległość powierzchnia-ognisko $20 \mathrm{~mm}$. Czas akwizycji widma wynosił $20 \mathrm{~s}$. Obszary zanalizowane zostały zaznaczone na obrazie SEM ramką (analiza obszaru) lub krzyżykiem (analiza punktowa) i ponumerowane ${ }^{39}$. W wyniku tych badań został dokładnie zobrazowany układ warstw technologicznych w poszczególnych partiach malowidła oraz określono precyzyjnie, jakie pigmenty i w jakich mieszaninach zostały użyte, a także jaki skład miała wyjątkowo cienka zaprawa obrazu oraz specyficzne podmalowanie.

Następnie wykonano analizę spoiw, stosując metodę spektroskopii w podczerwieni FTIR na dwóch próbkach warstw oryginalnych. Widmo FTIR zarejestrowano na spektrometrze FT-IR Bruker Alpha, z jednoodbiciową, 45-stopniową przystawką ATR z kryształem diamentowym w zakresie $4000-400 \mathrm{~cm}^{-1}$, z rozdzielczością $4 \mathrm{~cm}^{-1}$, uśredniając 128 skanów. W pomiarach wykorzystano detektor DTGS. Badania wykonała dr Łucja Rodzik-Czałka.

\section{Technologia i technika wykonania obrazu}

Podobrazie zabytku stanowi tablica ze sklejonych trzech desek modrzewiowych (z pozostawionymi sękami), wzmocnionych od odwrocia trzema oryginalnymi, pierwotnie ruchomymi szpongami, wprowadzonymi w tablicę na „jaskółczy ogon”. Odwrocie nosi wyraźne ślady obrabiania strugiem łukowym. Na górnej szpondze wycięta jest precyzyjnie i głęboko data: 1649, oznaczająca czas powstania obrazu ${ }^{40}$.

Poniżej na odwrociu widnieje namalowana czarną farbą inskrypcja łacińska: „Anno D(o)m(in)i 1714 Hic Imago ornata veste argentea uiuente Plebano Michaele Fe(li)”, co w tłumaczeniu można odczytać jako: „Roku Pańskiego 1714 ten obraz przyozdobił sukienką srebrną Proboszcz Michał Feliksiński”. W trakcie przeprowadzonych badań porównano stan obecny napisu w świetle białym z rozkładem pierwiastków uzyskanym w analizie MXRF, co uwidoczniło jego dwie warstwy chronologiczne. Pierwotna inskrypcja kredą ${ }^{41}$,

$39 \mathrm{~W}$ artykule zachowano pierwotną numerację analiz.

40 Liternictwo wyciętej daty na odwrociu Piety spójne jest z krojem liter namalowanej daty na ołtarzu w Wielogłowach.

${ }^{41}$ Sporządzanie napisów fundacyjnych kredą, najpewniej święconą, na odwrociach kultowych obrazów mogło być zjawiskiem powszechnym. Tak wykonaną inskrypcję można odnaleźć np. na malowanej na desce zasuwie głównego ołtarza w kościele w Gosprzydowej 
udokumentowana czytelnym rozkładem Ca na powierzchni rewersu, obecnie już zatarta i praktycznie niewidoczna, poprawiona została w nieznanym czasie prawie czarną farbą z dużą zawartością żelaza (Fe), przy czym z czasem zatarte zostały zupełnie dwie litery (il. 3).

Tablica wraz ze szpongami została w nieznanym czasie od odwrocia i z boków przemalowana minią $(\mathrm{Pb})$, a następnie brunatną farbą ze znaczną zawartością baru (Ba). Pozostawiono nieprzemalowaną jedynie część przytoczonego wyżej napisu, który urywa się nagle. Minia jako tlenek ołowiu stanowi nieprzepuszczalną barierę zarówno dla świateł analitycznych, jak i makrofluorescencji Rtg. Wykonane dotychczas badania wykazały szerszy zasięg pierwotnego napisu na rewersie obrazu, jednak możliwość odczytania go skończyła się na granicy tego przemalowania.

Od lica całość tablicy zagruntowano niezwykle cienką, choć czterowarstwową zaprawą kredowo-klejową z wyraźną zawartością glinokrzemianów (il. 4, ryc. 1, analiza 3/1-1 - pod światło wyraźnie uwidacznia się struktura desek). Gładką zaprawę pokryto podmalowaniem (imprimiturą), widocznym w odpryskach warstwy malarskiej w postaci szerokich pociągnięć pędzlem, tworzących naturalny gradient cienkiej, gładkiej, przejrzystej i mocno błyszczącej warstwy. Imprimiturę odnaleziono we wszystkich pobranych próbkach i w analizach SEM-EDS ustalono, że zmieszano ją z bieli ołowiowej $(\mathrm{Pb}) \mathrm{z}$ dodatkiem ochry (Fe), czerni kostnej (P, Ca) (ryc. 2, analiza 5/2-1) i kredy (kalcyt Ca, glinokrzemiany Al, Si) (ryc. 3, analiza 8/1-3). W obrębie tej warstwy znaleziono też drobinki gipsu (S, Ca) (ryc. 4, analiza 5/2-3).

Odkrycie gipsu w składzie podmalowania pozwoliło zweryfikować wynik analizy górnej warstwy zaprawy pobranej bezpośrednio w ubytku malatury (próbka 9), wykonanej za pomocą spektroskopii adsorpcyjnej w podczerwieni FTIR. W widmie FTIR wystąpiły tu pasma przy następujących częstościach: $2519,1793,870,711 \mathrm{~cm}^{-1}$ - charakterystyczne dla węglanu wapnia; $1735 \mathrm{~cm}^{-1}$ - dla związków olejnych; 1708, 1459, $1388 \mathrm{~cm}^{-1}$ - dla związków żywicznych; 1655, 1560, $1543 \mathrm{~cm}^{-1}$ - dla związków białkowych; 1026, 798, $779 \mathrm{~cm}^{-1}$ - dla glinokrzemianów; $603 \mathrm{~cm}^{-1}$ - charakterystyczne dla gipsu (siarczan wapnia).

Stwierdzono, że odkryte pasmo przy $603 \mathrm{~cm}^{-1}$, charakterystyczne dla gipsu, pochodzi z warstwy podmalowania pobranego wraz z zaprawą, skoro

(pow. brzeski) z przedstawieniem Matki Boskiej Gosprzydowskiej, gdzie umieścił ją w $1700 \mathrm{r}$. fundator obrazu. Niestety, w trakcie zabiegów czyszczenia, zabezpieczania i „odnawiania” obrazów wiele z tych inskrypcji uległo zniszczeniu, ale warto ich szukać metodą makrofluorescencji Rtg. 
żadna z analiz SEM-EDS przekrojów bocznych nie potwierdziła jego występowania w zaprawie. Znalezione w widmie FTIR wtrącenia związków olejno-żywicznych w zaprawie kredowo-klejowej widoczne były na wszystkich przekrojach bocznych w postaci znacznego zaciemnienia górnej warstwy gruntu. Przypuszczalnie w czasie którejś renowacji obraz został tak mocno przesycony tłustym spoiwem, że spenetrowało ono przez krakelury i wysyciło nadmiernie najwyższą warstwę zaprawy, co w konsekwencji spowodowało późniejsze stopniowe, pęcherzykowate odspajanie się chudej warstwy malarskiej od zatłuszczonego podłoża. Zatłuszczenie zaprawy nie mogło raczej być wynikiem błędu twórcy obrazu, gdyż chuda temperowa warstwa malarska nie miałaby od początku właściwej przyczepności i odpadając, dawno uległaby zniszczeniu.

W celu rozpoznania spoiw użytych przez twórcę obrazu poddano analizie za pomocą spektroskopii adsorpcyjnej w podczerwieni FTIR próbkę pobraną z samej warstwy malarskiej (próbka 10), gdzie w widmie FTIR wystąpiły pasma przy następujących częstościach: 1702, 1384, 1321, $1241 \mathrm{~cm}^{-1}$ - charakterystyczne dla związków żywicznych; 1652, 1641, $1543 \mathrm{~cm}^{-1}$ - dla związków białkowych; 872, $710 \mathrm{~cm}^{-1}$ - charakterystyczne dla węglanu wapnia; 1030, $777 \mathrm{~cm}^{-1}$ - dla glinokrzemianów; 667, $597 \mathrm{~cm}^{-1}$ - dla gipsu (siarczan wapnia). Stwierdzono, że obraz namalowany został w technice tempery (spoiwo białkowe $)^{42} \mathrm{z}$ laserunkami żywicznymi (które zawsze miały w składzie sykatywę ołowiową, co stwierdzono w analizach SEM-EDS).

Co ciekawe, modelunki wszystkich partii artysta wykonał alla prima, w jednej warstwie temperowego malowidła ${ }^{43}$, co świadczy o jego dużej sprawności malarskiej. Dodatkowo wzbogacił poszczególne partie o różnobarwne laserunki żywiczne, które nakładał w większości na wyschniętą warstwę spodnią. Zastosował więc technikę pośrednią pomiędzy tradycyjną wieloetapową metodą budowania obrazu a prawdziwym alla prima.

W pierwszej kolejności malarz wykonał farbą przy użyciu cienkiego pędzla bardzo subtelny rysunek kompozycji. W trakcie badań udało się pobrać próbkę z jego fragmentem, widocznym na przekroju w postaci ciemnej kreski. Analiza SEM-EDS jej składu pierwiastkowego wykazała obecność Mn, Fe, Si,

42 Wszyscy dotychczasowi badacze i konserwatorzy uważali obraz za namalowany techniką olejną, jako taki figuruje też w dokumentach WUOZ.

43 Ta technika malarska jest zwykle stosowana w malarstwie olejnym i polega na wykonaniu malowidła „od razu”, „przy pierwszej próbie”, bez sukcesywnego budowania kompozycji przez metodyczne nakładanie kolejnych warstw malarskich, tak charakterystyczne dla tempery. 
Al, co świadczy o użyciu przez malarza farby opartej na pigmencie ziemnym, ciemnobrązowej umbrze (ryc. 5, analiza 1/4-4].

Elementy tła namalowane są bardzo cienko, laserunkowo, z użyciem spoiwa żywicznego z sykatywą ołowiową, obecnie pociemniałego. W partiach krajobrazu zastosowane zostały pigmenty miedziowe, głównie błękitny azuryt oraz pigmenty ziemne o różnych odcieniach ugru i brązu, z dodatkiem bieli ołowiowej. W przekroju bocznym poddanym analizie SEM-EDS warstwę malarską stanowi mieszanina azurytu $(\mathrm{Cu})$ (ryc. 6, analiza 3/2-2), pigmentów ziemnych, w tym ziemi czerwonej ( $\mathrm{Fe}, \mathrm{Al}, \mathrm{Si}$ ), czerni oraz przypuszczalnie kredy - kalcytu (Ca). Przeprowadzone w późniejszym czasie prace konserwatorskie odsłoniły szczegóły krajobrazowego tła: szkicowo namalowane skały i skąpą roślinność.

Karnacje oraz szaty namalowane zostały gęstszą farbą temperową, w partiach świateł impastowo. Malarz zastosował bogatą, szlachetną paletę pigmentów: biel ołowiową, aurypigment/realgar, glejtę ołowiową, vermilion, minię, organiczny kraplak, czerń kostną, roślinną i sadzę(?). Zadziwia użycie przez niego aż trzech różnych błękitów: azurytu, smalty i ultramaryny, przy czym o ile azuryt posłużył artyście do modyfikowania, oziębiania tonu koloru, o tyle pozostałe niebieskie pigmenty były podstawą do zbudowania różnych części szat Marii. Warto zauważyć, że podobny zabieg zastosował półtora wieku wcześniej Giovanni Bellini, który w Piecie namalowanej dla Pałacu Dożów około 1505 roku, znajdującej się obecnie w zbiorach Galleria dell'Accademia w Wenecji ${ }^{44}$, wyraźnie zróżnicował dwie połowy tego samego płaszcza okrywającego postać Marii, realizując jedną w intensywnie niebieskim kolorze, drugą zaś malując na fioletowo. Przez zastosowanie przypisanego zwyczajowo osobie Marii błękitu ${ }^{45}$ równocześnie z fioletem, wywodzącym się z królewskiej purpury, który już w średniowieczu stał się w kolorem Pasji Chrystusa, w symboliczny sposób artysta pokazał współuczestnictwo Matki Bożej w zbawczej Męce Syna.

Martwe ciało Chrystusa zostało namalowane w sinozielonkawym kolorze, kontrastującym z różową karnacją Marii. W obu przypadkach głównym składnikiem warstwy malarskiej jest biel ołowiowa $(\mathrm{Pb})$, w którą wmieszano pozostałe pigmenty (il. 5). Karnacja Marii została zbudowana na bazie bieli ołowiowej z dodatkiem vermillionu (il. 6), natomiast zimny w odbiorze i bardzo jasny koloryt ciała Chrystusa zawdzięcza swój odcień głównie dodatkowi

44 https://www.gallerieaccademia.it/pieta-0, dostęp 25 września 2021.

45 Maria Rzepińska, Historia koloru $w$ dziejach malarstwa europejskiego, t. 1 (Warszawa: Arkady, 1989), 131-132. 
błękitnego azurytu (ryc. 7, analiza 1/1-5). Analizy SEM-EDS przekroju wykazały również domieszkę ciemnoczerwonej minii $(\mathrm{Pb})$, nadającej karnacji lekko cielisty kolor, a także subtelne zmiany odcieni farby dzięki dodatkom ochry (Fe) i aurypigmentu (As, S) (il. 7-8).

Co ciekawe, w składzie karnacji Chrystusa występuje niewielka, śladowa domieszka smalty (Co, Si, As) zarejestrowana w obrębie kolana postaci Chrystusa. Cienie, w kolorze ciemnych brązów, modelowano umbrą (Mn), zbieżną w odcieniu z pigmentem, którym wykonano rysunek kompozycji. Również zarost Chrystusa i jego włosy namalowano precyzyjnie ciemnymi pigmentami ziemnymi ze znaczną zawartością manganu (Mn) (il. 8 i 9).

Istotnym problemem do rozwiązania przed rozpoczęciem konserwacji-restauracji obiektu było rozstrzygnięcie autentyczności namalowanego wokół głowy Marii wyjątkowego nimbu. W jego obrębie widoczna była pasowa odkrywka, niszcząca, jak się ostatecznie okazało - fragment oryginału. Nie udało się dociec, kto i kiedy ją wykonał, jednak musiało to nastąpić już po koronacji obrazu w 1999 roku (nie widać jej na zdjęciach z uroczystości).

Badania SEM-EDS przekroju z aureoli na granicy z chustą Marii (il. 10) wykazały, że na podmalowaniu z bieli ołowiowej, kredy, ochry i czerni kostnej występuje intensywnie żółta warstwa malarska, w której składzie wykryto w równych proporcjach As i S (ryc. 8, analiza 6/3-3). Kolor ziaren oraz proporcje As i S sugerują użycie realgaru. Na podstawie dotychczas wykonanych badań nie można jednak w stu procentach określić, czy mamy do czynienia z aurypigmentem, czy realgarem. Na intensywnie żółtej warstwie leży cieńsza, jaśniejsza, również żółta warstwa złożona z bieli ołowiowej (Pb) i jasnożółtych ziaren siarczku arsenu (As, S) (ryc. 9, analiza 6/3-7).

Pomarańczowy okrąg aureoli leży na imprimiturze z bieli ołowiowej $(\mathrm{Pb})$ z dodatkiem ochry (Fe), czerni kostnej (C, P), ocieplonej vermillionem $(\mathrm{Hg})$, na której położono jasne podmalowanie $\mathrm{z}$ aurypigmentu/realgaru (As, S) (analiza 4.2/2-2, w dokumentacji badań) zmieszanego z minią (Pb) (analiza 4.2/2-1, w dokumentacji badań). Widoczną intensywnie pomarańczową warstwę malarską zmieszano z minii, glejty ołowiowej, odrobiny bieli ołowiowej $(\mathrm{Pb})$ i vermillionu ( $\mathrm{Hg}$ ) (analiza 4.1/1-3, 4.1/1-4, w dokumentacji badań) i bez wątpienia jest ona warstwą historyczną, oryginalną (il. 11-12).

Leżącą na aureoli warstwę malarską tworzącą chustę Marii zmieszano z większej ilości pigmentów: umbry (Mn, $\mathrm{Fe}, \mathrm{Si}, \mathrm{Al}$ ) (ryc. 10, analiza 6/3-12), czerni kostnej (P) i czerni roślinnej (K) (ryc. 11, analiza 6/3-13), z dodatkiem drobnych ziaren vermillionu (HgS) (analiza 6/3-10, 6/3-15, w dokumentacji 
badań). W warstwie odnaleziono też siarczek arsenu (As, S) (ryc. 12, analiza 6/3-11) świadczący o użyciu aurypigmentu lub realgaru (?), a także biel ołowiową $(\mathrm{Pb})$, dodane dla rozjaśnienia farby.

Fragment długiej chusty opadającej z ramienia Marii, w odbiorze wizualnym brunatnofioletowej, został namalowany smaltą. W makrofluorescencji Rtg prócz dużej zawartości kobaltu (Co) wyodrębniono na jego obszarze słaby sygnał potasu (K) (il. 13), również charakterystycznego dla smalty. Analiza SEM-EDS przekroju poprzecznego pobranego z cienia płaszcza Marii potwierdziła obecność szklistych ziaren smalty, o przeważającej zawartości krzemu (Si) i śladowej obecności arsenu, kobaltu, potasu, wapnia i niklu (il. 14, ryc. 13, analiza 2/2-5).

Błękitny płaszcz Marii namalowany został drobnoziarnistą ultramaryną. Dla makrofluorescencji Rtg była ona przezroczysta (il. 15). W analizach SEM-EDS w jej składzie przeważały glinokrzemiany (Al, Si) z niewielkim udziałem sodu, a także wapnia, pochodzącego prawdopodobnie od kalcytu obecnego w złożu (ryc. 14, analiza 7/3-1). W celu uzyskania odpowiedniego odcienia błękit mieszano z bielą ołowiową $(\mathrm{Pb})$, kredą, czernią i ochrą $(\mathrm{Fe})$. Ostatnią warstwę na sukni stanowił laserunek żywiczny.

Modelunek różowej sukni Marii wykonany został bielą ołowiową zmieszaną z kraplakiem (w którym wykryto sporą obecność ołowiu, pochodzącego ze sposobu przygotowywania spoiwa żywicznego, najpewniej gotowanego w naczyniu ołowianym, może z dodatkowymi kawałkami metalu). Na taki dobrze już wyschnięty podkład artysta nakładał warstwę czerwonego laserunku organicznego (il. 15), prawdopodobnie kraplaku, w którego widmie występuje duża ilość węgla i glinu (C, Al), a także ołów $(\mathrm{Pb})$, pochodzący również najpewniej od sykatywy (ryc. 15 , analiza $5 / 1-6$ ).

W ciemnej partii tła obraz został dwukrotnie przemalowany (il. 16). Całość tła pokrywało przemalowanie rozbieloną czernią (P, Ca, Ba) z domieszką ochry (Fe), pochodzące z poprzednich konserwacji. Część spoiw żywicznych uległa całkowitemu ściemnieniu, wręcz sczernieniu. Wykonana w trakcie wstępnych badań obiektu odkrywka ukazała oryginalne, również czarne, choć o dużo głębszej barwie tło, niestety bardzo zniszczone, przetarte. Pod przemalowaniami znajduje się gruba warstwa czerni, najprawdopodobniej o charakterze bolusu o składzie: czerń kostna (P) z dodatkiem glinki (Al, Si, $\mathrm{Mg}$, Ca) (ryc. 16, analiza 8/1-4), na której natrafiono na mikrośladowe pozostałości srebra (Ag) (ryc. 17, analiza 8/1-9), co nie dało jednak podstaw do zmiany tła obrazu na srebrne. 
Na powierzchni obrazu znaleziono liczne retusze, głównie olejne, wykonane na większych ubytkach oryginału na kitach kredowo-klejowych, o nieco zmienionym kolorze (1971 r.?), oraz wykonane bezpośrednio na drewnie w licznych drobnych ubytkach zaprawy, które zmatowiały i straciły swój kolor.

Realizacja programu badawczego pozwoliła w sposób kompleksowy rozpoznać budowę obrazu Piety oraz praktykę warsztatową jej twórcy, jej wyniki zaś stanowiły podstawę do sformułowania programu prac konserwatorskich dla obiektu. Sprawny, dwuwarstwowy sposób budowania malowidła (w schemacie: podkład / modelunek formy - wykończenie / modelunek laserunkami) świadczy o dużej biegłości wykonawcy, a zastosowane materiały wskazują, że dobrze znał swoje rzemiosło. Te ustalenia, niezależnie od oceny formalnej dzieła, prowadzą do wniosku, że twórcą obrazu nie był prowincjonalny artysta, lecz dobrze wykształcony, na co dzień praktykujący malarz, obyty z „nowoczesnym” sposobem malowania. Zastosowanie spoiwa temperowego każe widzieć w nim równocześnie mistrza technologicznie głęboko osadzonego w dobrej rzemieślniczej tradycji warsztatowej - raczej północnoeuropejskiej, w której obrazy na podobraziach drewnianych wciąż tak właśnie budowano ${ }^{46}$.

Niniejsza analiza nie rozstrzyga ostatecznie kwestii atrybucji zaprezentowanego dzieła z uwagi na brak bazy porównawczej. Nie opublikowano bowiem dotychczas podobnych analiz techniczno-technologicznych dla dzieł zbliżonych do niego stylowo i formalnie, w tym Piety z Wielogłów oraz wspomnianej Ostatniej Wieczerzy z Muzeum Narodowego w Krakowie - jedynego znanego nam dziś obrazu niderlandzkiego malarza, kształconego w Rzymie, a pracującego później w Małopolsce, któremu przypisuje się Pietę z Czarnego Potoku. Przeprowadzony projekt badawczy stanowi jednak istotny wkład w stopniowo powiększającą się bazę danych o praktykach warsztatowych siedemnastowiecznych malarzy działających na terenie Rzeczypospolitej, będącą podstawą dla ewentualnych porównań i potwierdzeń atrybucji dzieł sztuki.

\section{Finansowanie:}

E-RIHS.pl w ramach 3. naboru wniosków MOLAB/FIXLAB PL w 2019 r.

46 Dla przypomnienia: dotychczas określano omawianą Pietę jako obraz olejny, podobnie jak większość obrazów XVII-wiecznych, właściwie bez podstaw, bez wykonania badań spoiw. O ile badania pigmentów są szeroko przeprowadzane przy okazji konserwacji dzieł sztuki, o tyle analizy spoiw są dużo rzadsze, nie mamy zatem właściwego osądu co do rzeczywistego procentowego udziału mediów temperowych i olejno-żywicznych stosowanych przez XVII-wiecznych malarzy w Rzeczypospolitej. 


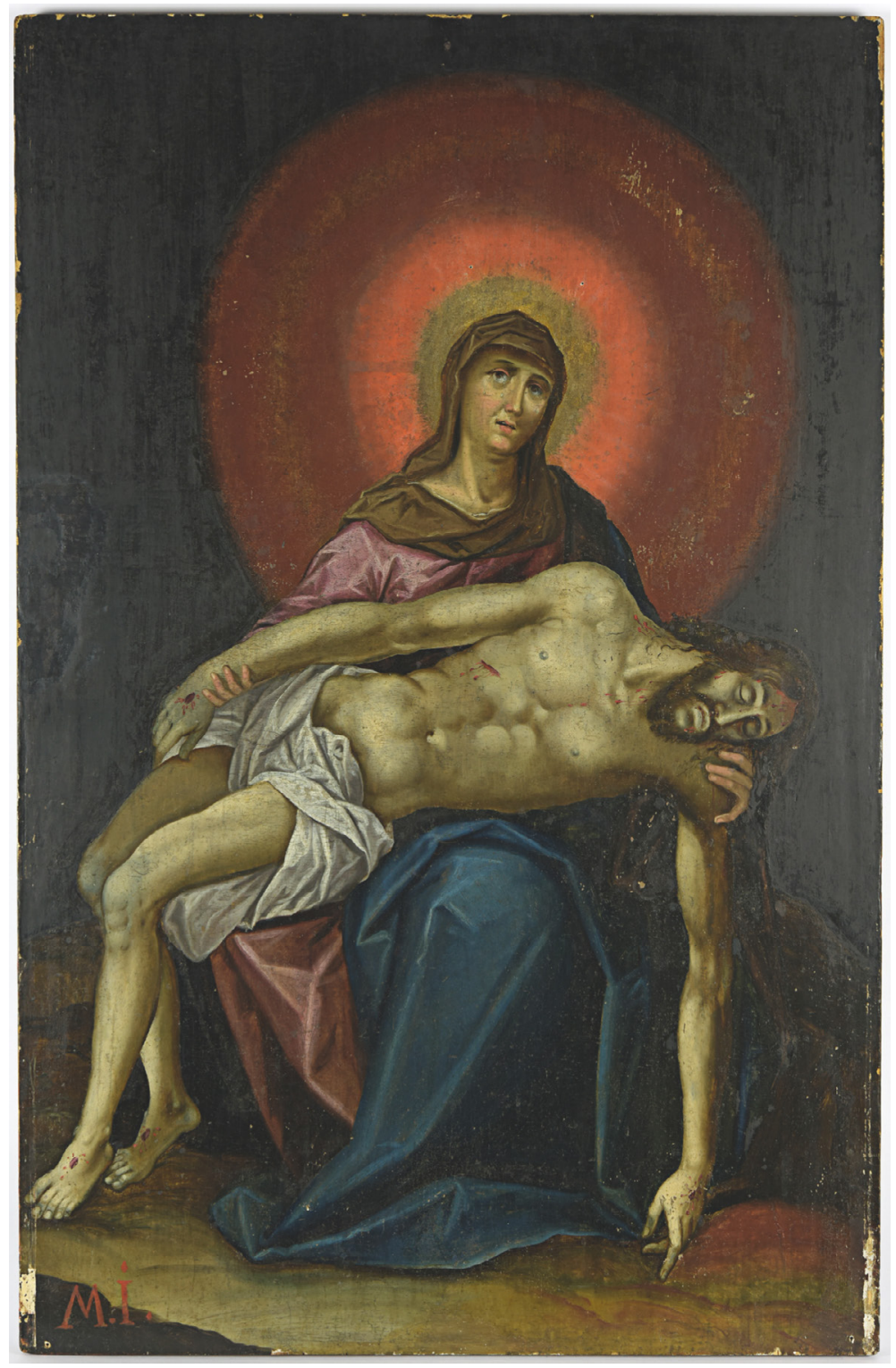

Il. 1. Czarny Potok, kościół pw. św. Marcina Biskupa, Pieta (1649). Fotografia w świetle VIS, awers (2019). Fot. A. Borowska 


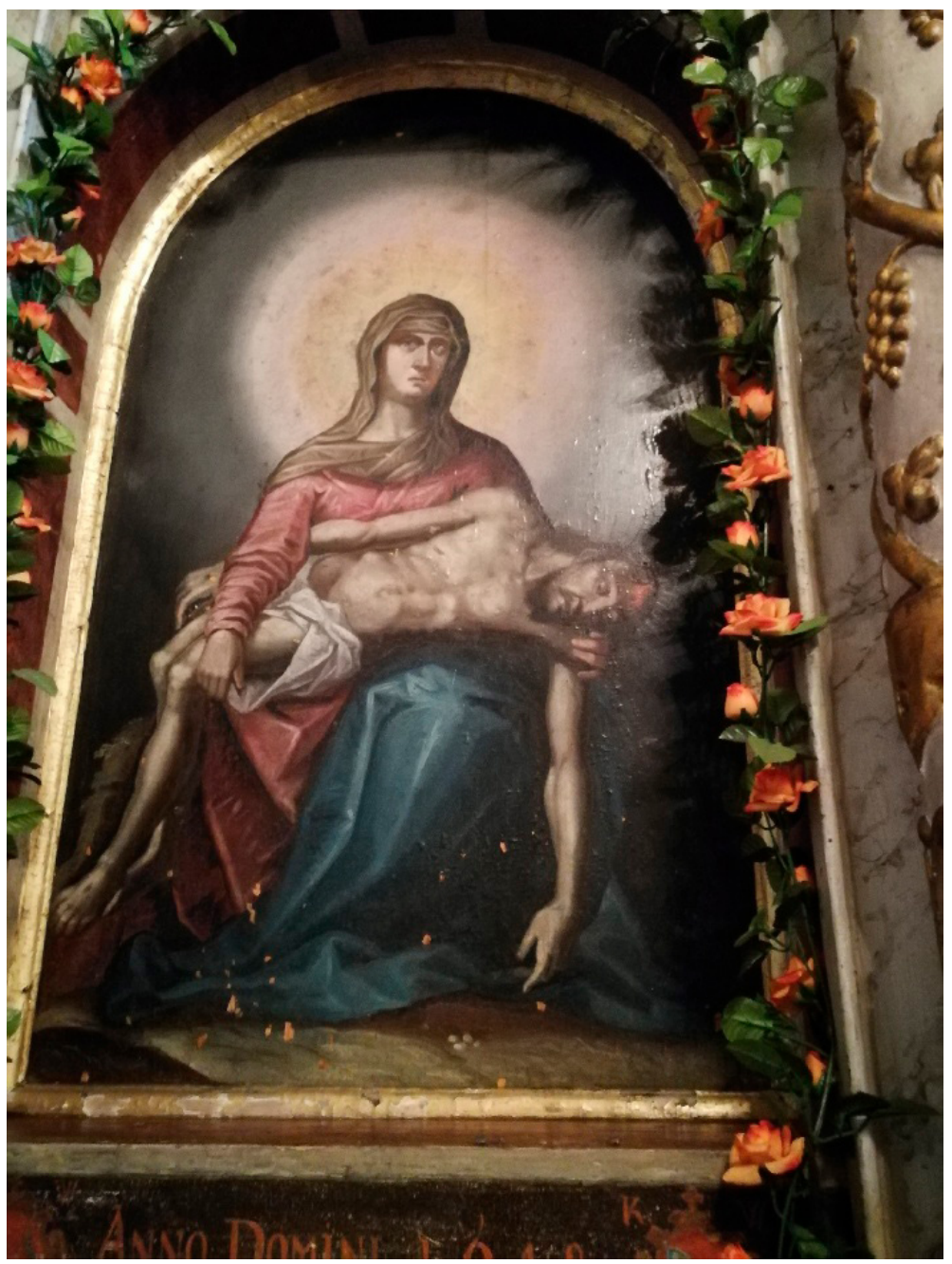

Il. 2. Wielogłowy, kościół pw. WNMP, Pieta (1648). Fot. A. Borowska 
a

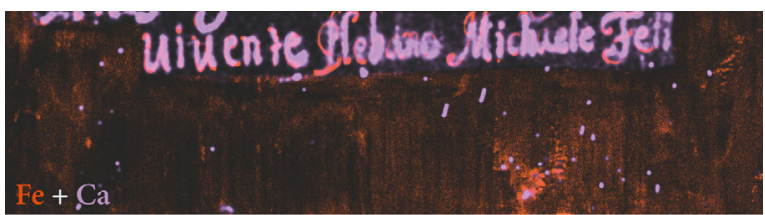

b

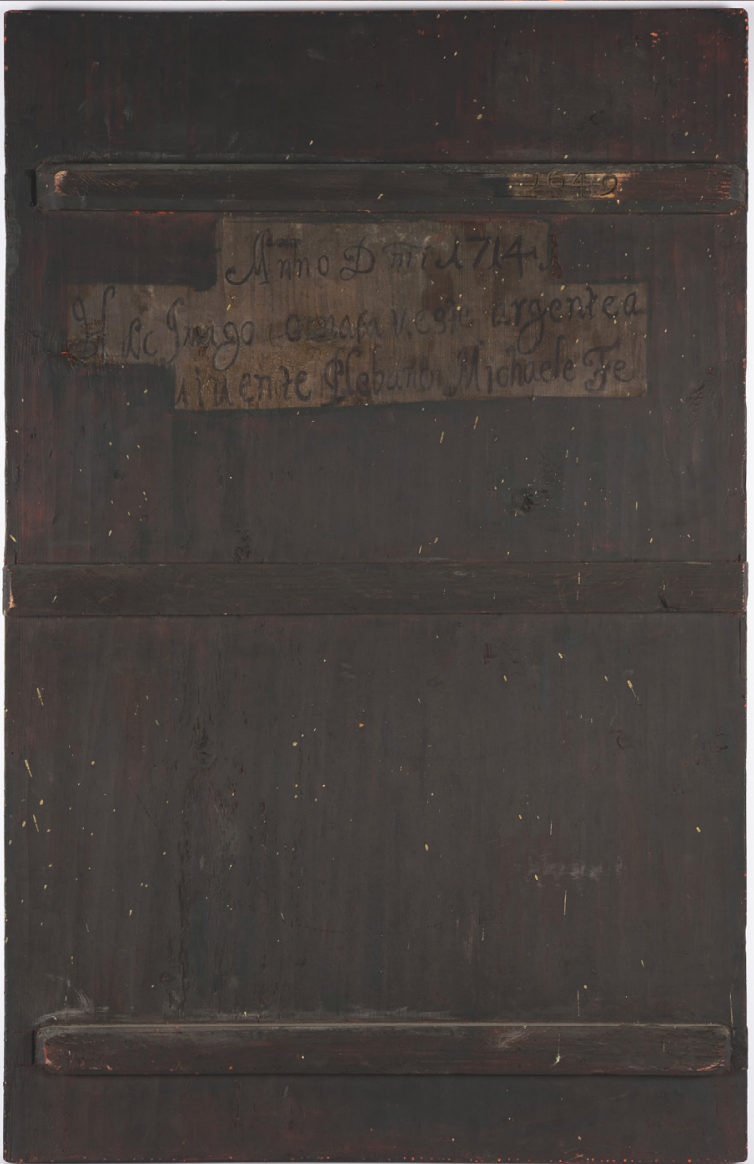

Il. 3. Czarny Potok, kościół pw. św. Marcina Biskupa, Pieta (1649), rewers z łacińską inskrypcją. Napis kredą (Ca) poprawiony ciemną, umbrową farbą (Fe) - znikły dwie litery. Fot. A. Borowska, M. Goryl, oprac. A. Borowska a - złożenie rozkładu pierwiastków MXRF, ukazujące dwie warstwy chronologiczne napisu, $\mathrm{b}$ - fotografia w świetle VIS (2019) 


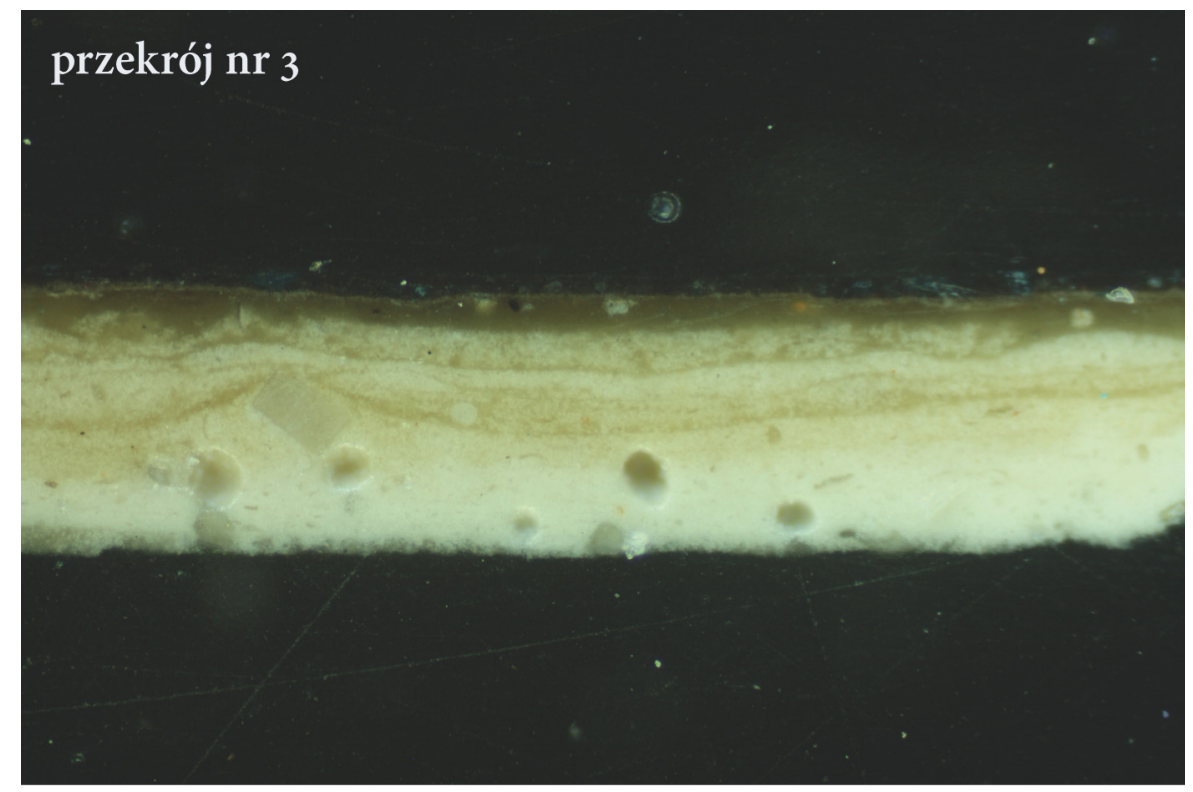

Il. 4. Czarny Potok, kościół pw. św. Marcina Biskupa, Pieta (1649). Przekrój boczny próbki pobranej z krajobrazowego tła. Fot. M. Walczak

Warstwę malarską stanowi mieszanina azurytu $(\mathrm{Cu})$ (analiza 3/2-2), pigmentów ziemnych, w tym ziemi czerwonej (Fe, $\mathrm{Al}, \mathrm{Si}$ ), czerni oraz przypuszczalnie kredy - kalcytu (Ca). Zastosowano tu spoiwo żywiczne z sykatywą ołowiową, obecnie bardzo pociemniałe. Zaprawa kredowo-klejowa, z wyraźną zawartością glinokrzemianów, czterowarstwowa 


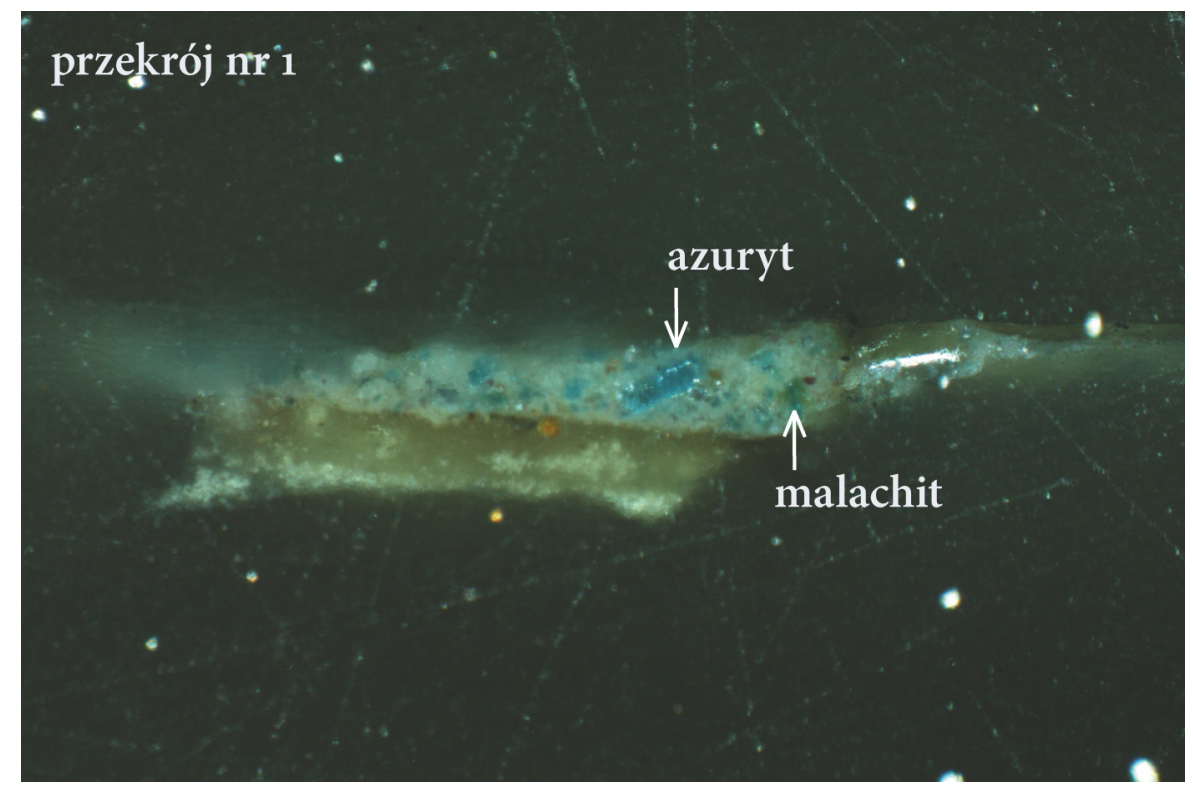

Il. 5. Czarny Potok, kościół pw. św. Marcina Biskupa, Pieta (1649). Przekrój boczny próbki pobranej z kolana Chrystusa. Fot. M. Walczak

Zasadniczym składnikiem warstwy karnacji jest biel ołowiowa, w którą wmieszano pozostałe pigmenty, głównie azuryt (Cu) (analiza 1/1-5), który częściowo zmienił się w malachit. W przekroju odnaleziono domieszkę ciemnoczerwonej minii $(\mathrm{Pb})$, nadającą karnacji lekko cielisty kolor. Malarz zmieniał odcień farby również dzięki dodatkowi ochry (Fe) i aurypigmentu (As, S) 


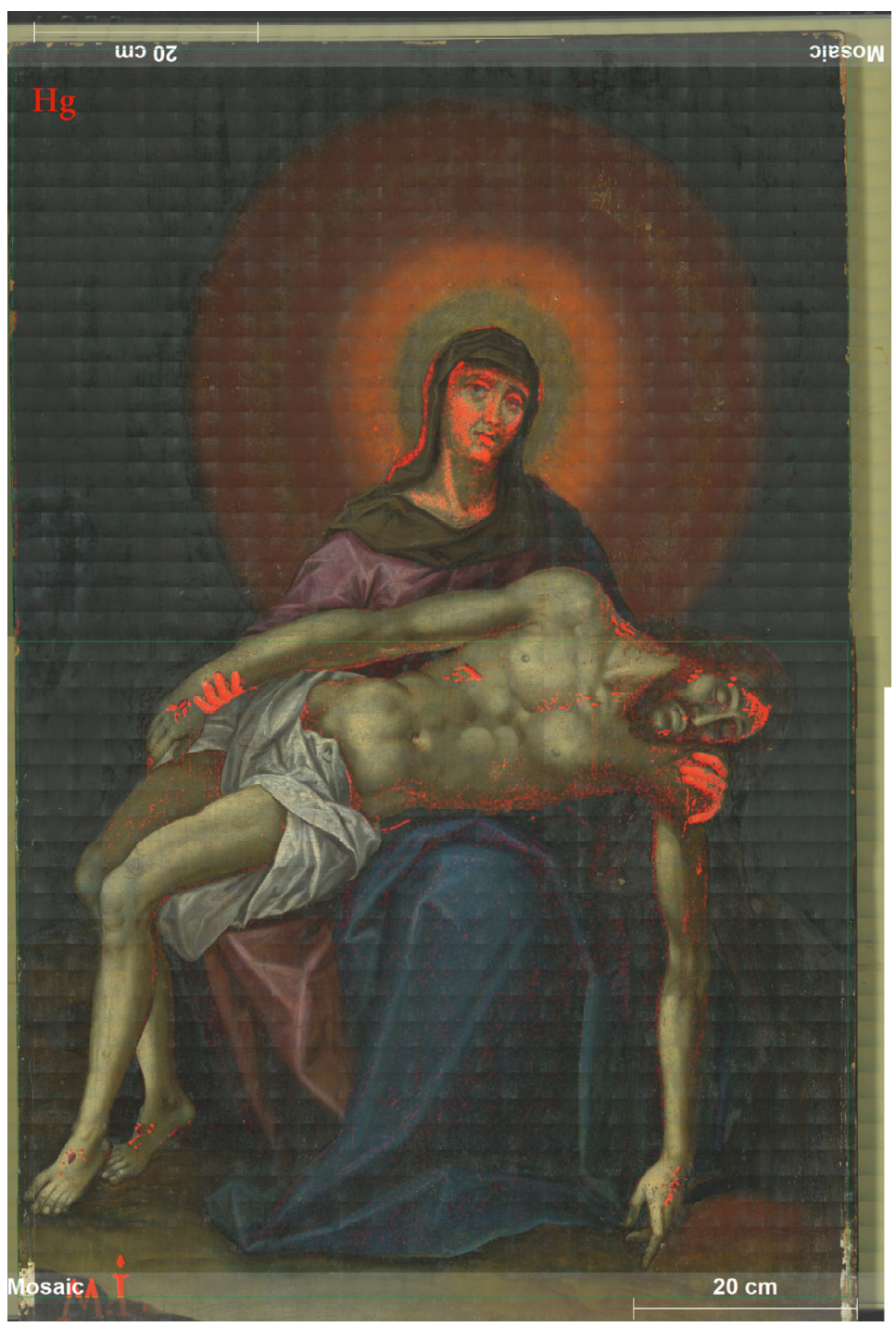

Il. 6. Czarny Potok, kościół pw. św. Marcina Biskupa, Pieta (1649). MXRF awersu: Video Mosaic + rozkład Hg. Fot. M. Goryl, oprac. A. Borowska Karnacja Marii została zbudowana na bazie bieli ołowiowej z dodatkiem vermillionu 


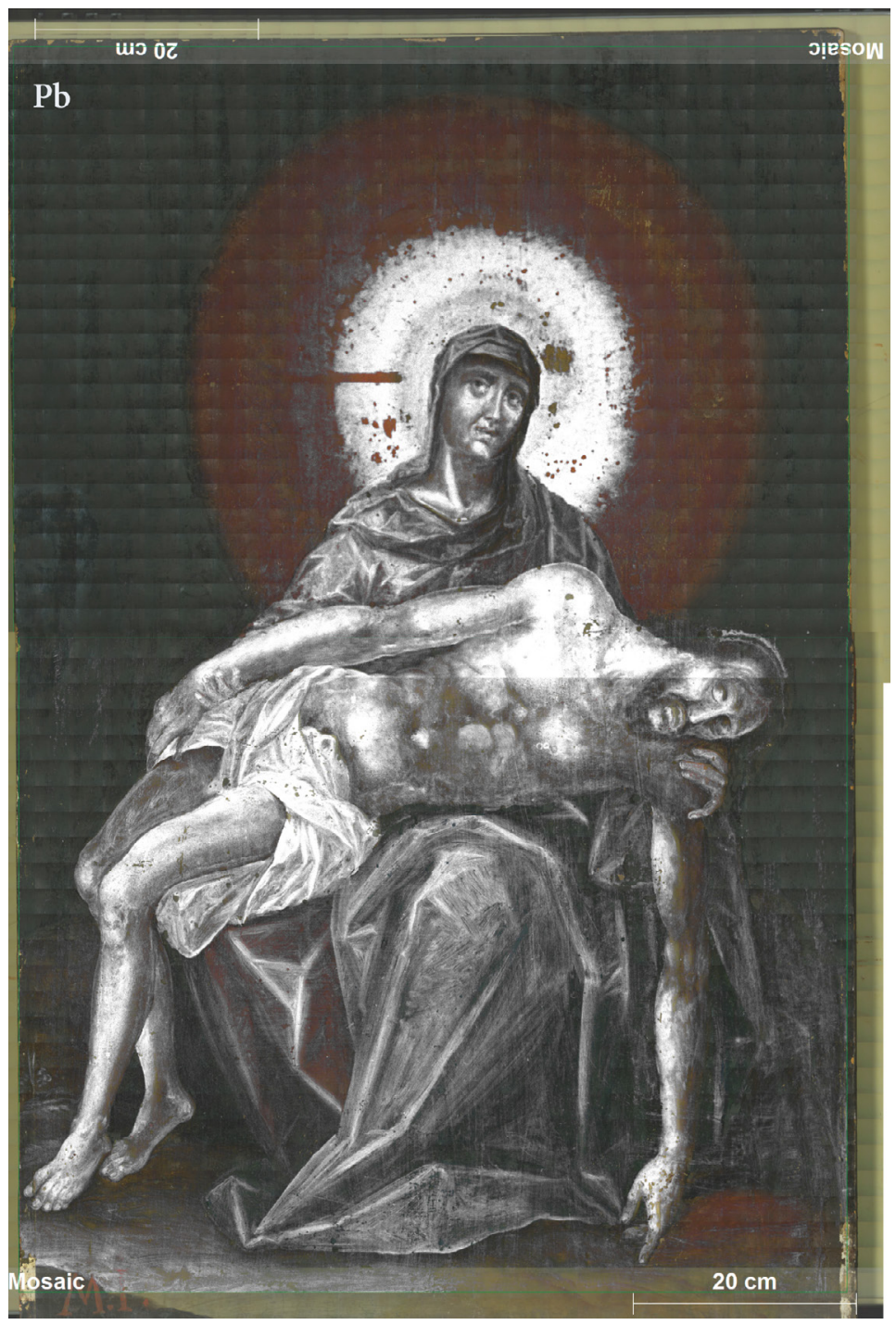

Il. 7. Czarny Potok, kościół pw. św. Marcina Biskupa, Pieta (1649). MXRF awersu: Video Mosaic + rozkład Pb. Fot. M. Goryl, oprac. A. Borowska 


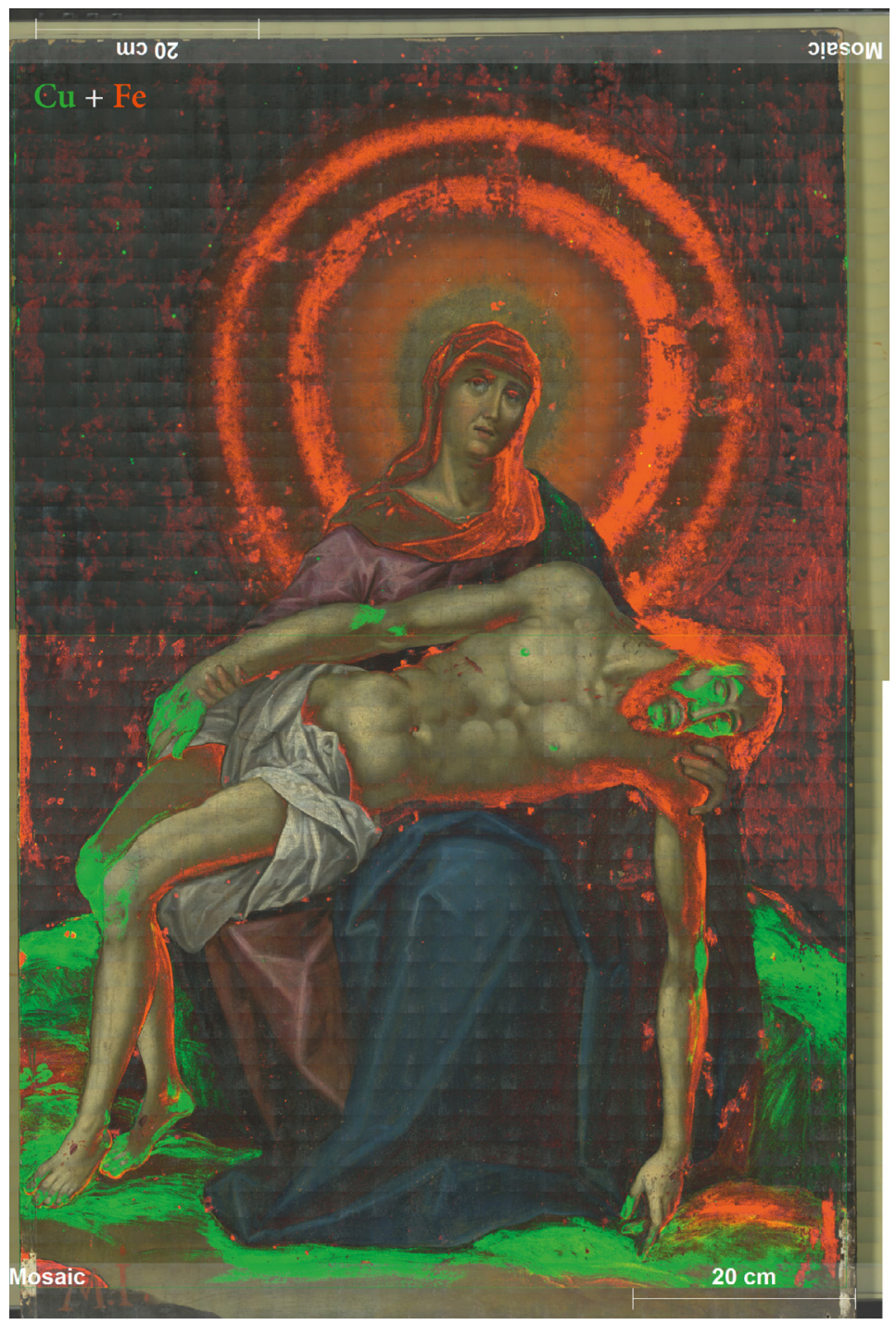

Il. 8. Czarny Potok, kościół pw. św. Marcina Biskupa, Pieta (1649). MXRF awersu: Video Mosaic + rozkład Cu + Fe. Fot. M. Goryl, oprac. A. Borowska Karnacja Chrystusa została zbudowana na bazie bieli ołowiowej z dodatkiem azurytu i pigmentów ziemnych 


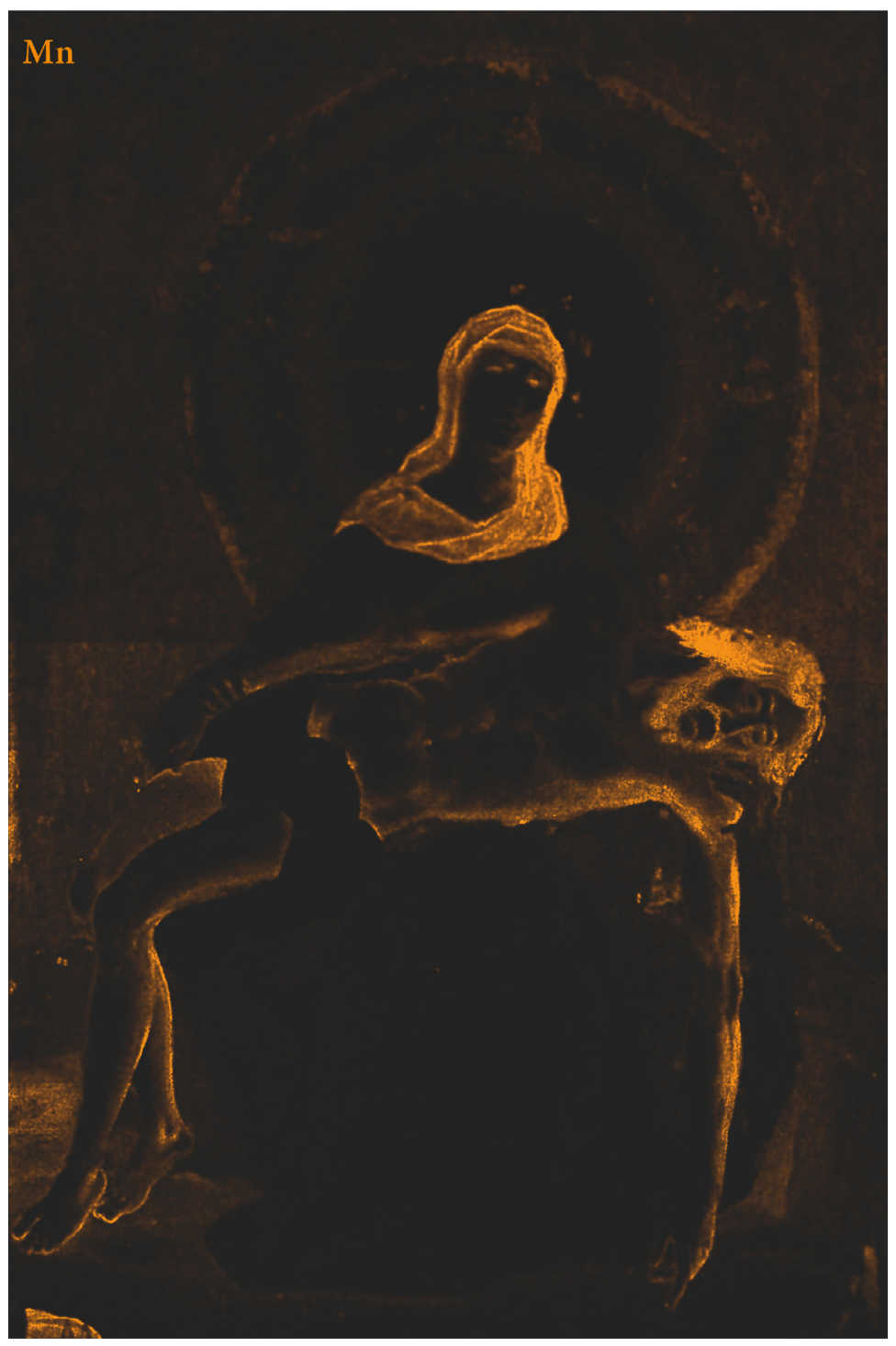

Il. 9. Czarny Potok, kościół pw. św. Marcina Biskupa, Pieta (1649). Rozkład Mn (MXRF) na awersie obrazu. Fot. M. Goryl 


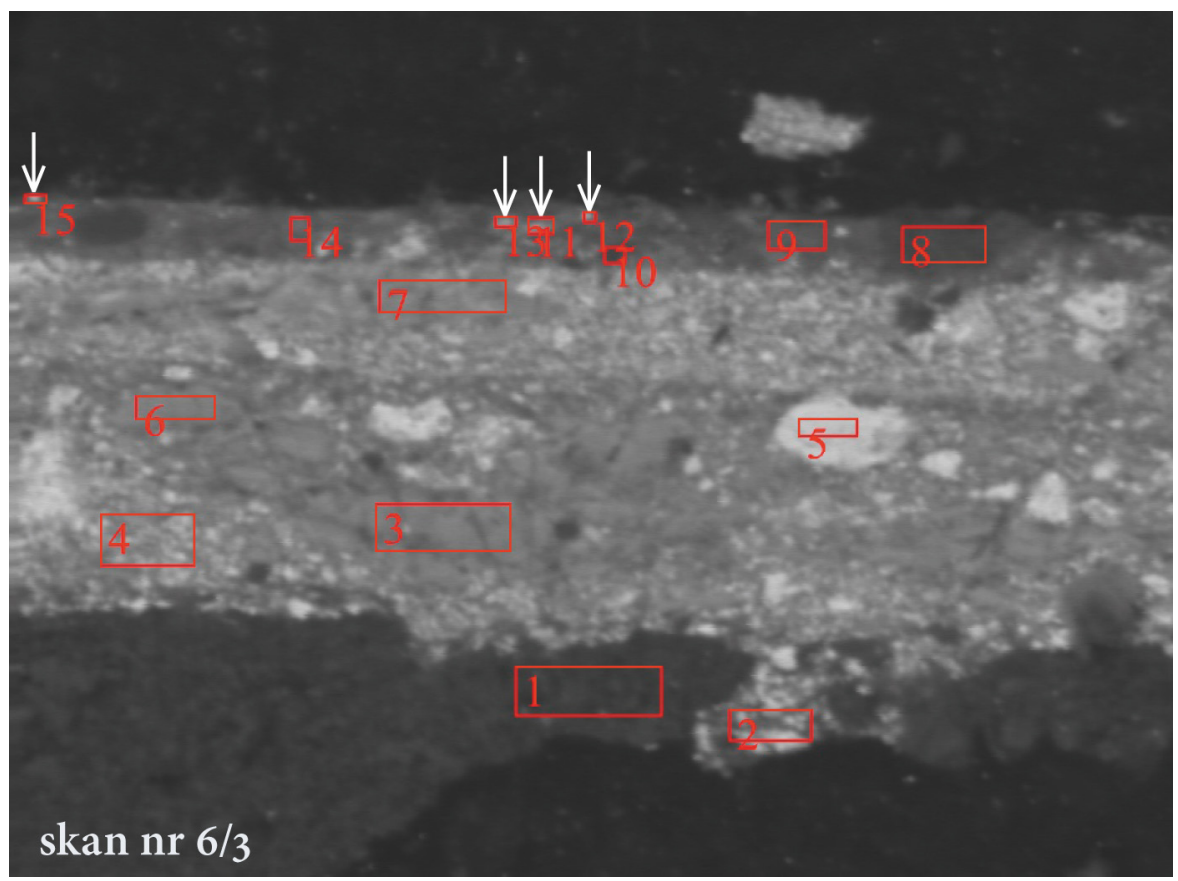

Il. 10. Czarny Potok, kościół pw. św. Marcina Biskupa, Pieta (1649). Skan SEM-EDS przekroju poprzecznego z chusty Marii (fragment na nimbie). Wyk. M. Goryl

Warstwa malarska to mieszanina większej ilości pigmentów, tworzy ją umbra (Mn, Fe, Si, Al) (analiza 6/3-12), czerń kostna (P) i czerń roślinna (K) (analiza 6/3-13). Małe drobne ziarenka to dodatek vermillionu (HgS) (analiza 6/3-10, 6/3-15). W warstwie znajdujemy też siarczek arsenu (As, S) (analiza 6/3-11) - aurypigment lub realgar (?), a także biel ołowiową $(\mathrm{Pb})$, dodane dla rozjaśnienia farby 

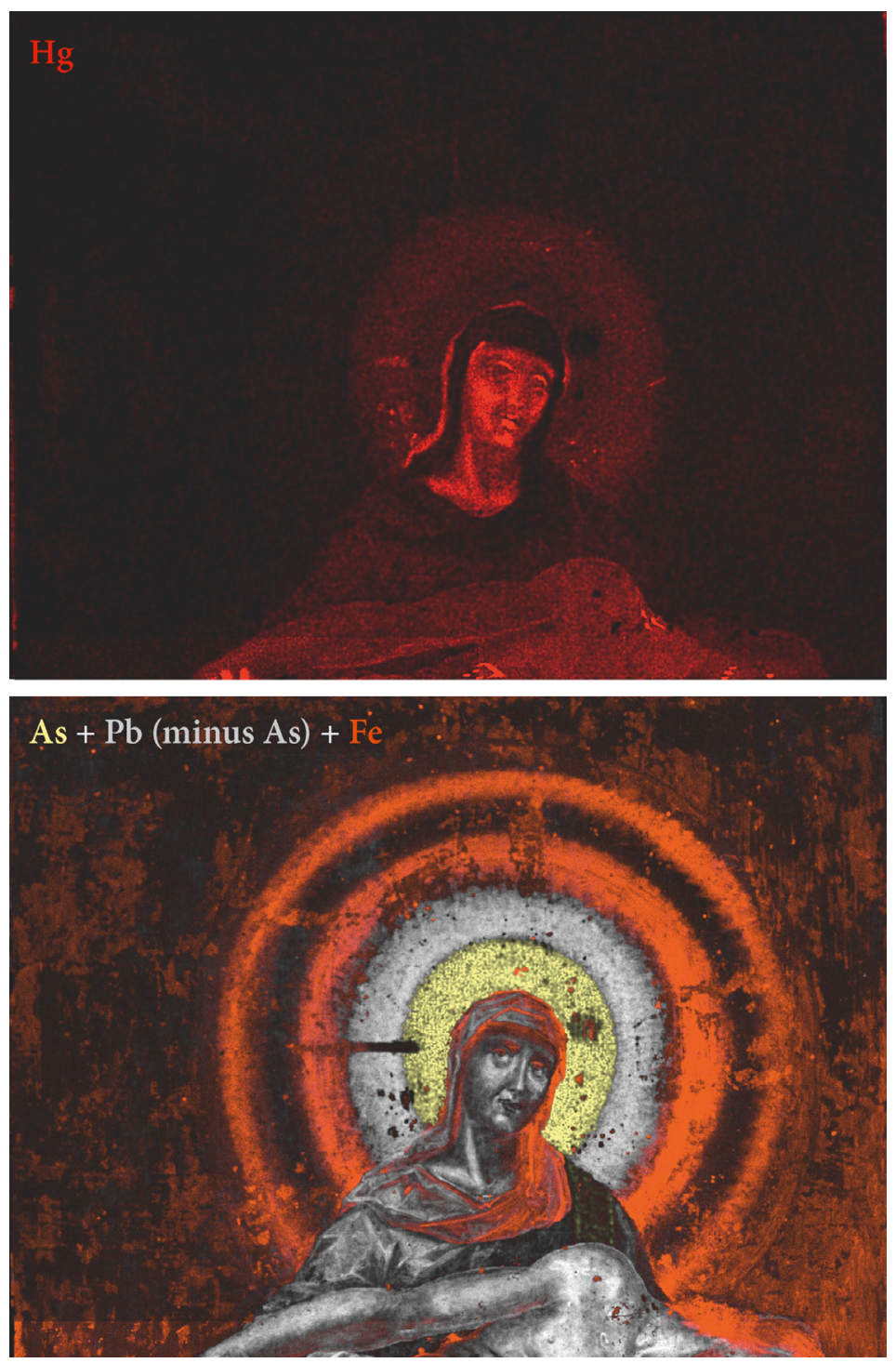

Il. 11. Czarny Potok, kościół pw. św. Marcina Biskupa, Pieta (1649), awers, nimb Marii. Rozkład pierwiastków w makrofluorescencji rentgenowskiej (MXRF). Fot. M. Goryl, oprac. W. Borowski Rozkład pierwiastków: $\mathrm{Hg}$, złożenie $\mathrm{As}+\mathrm{Pb}$ (po odjęciu As) + Fe 

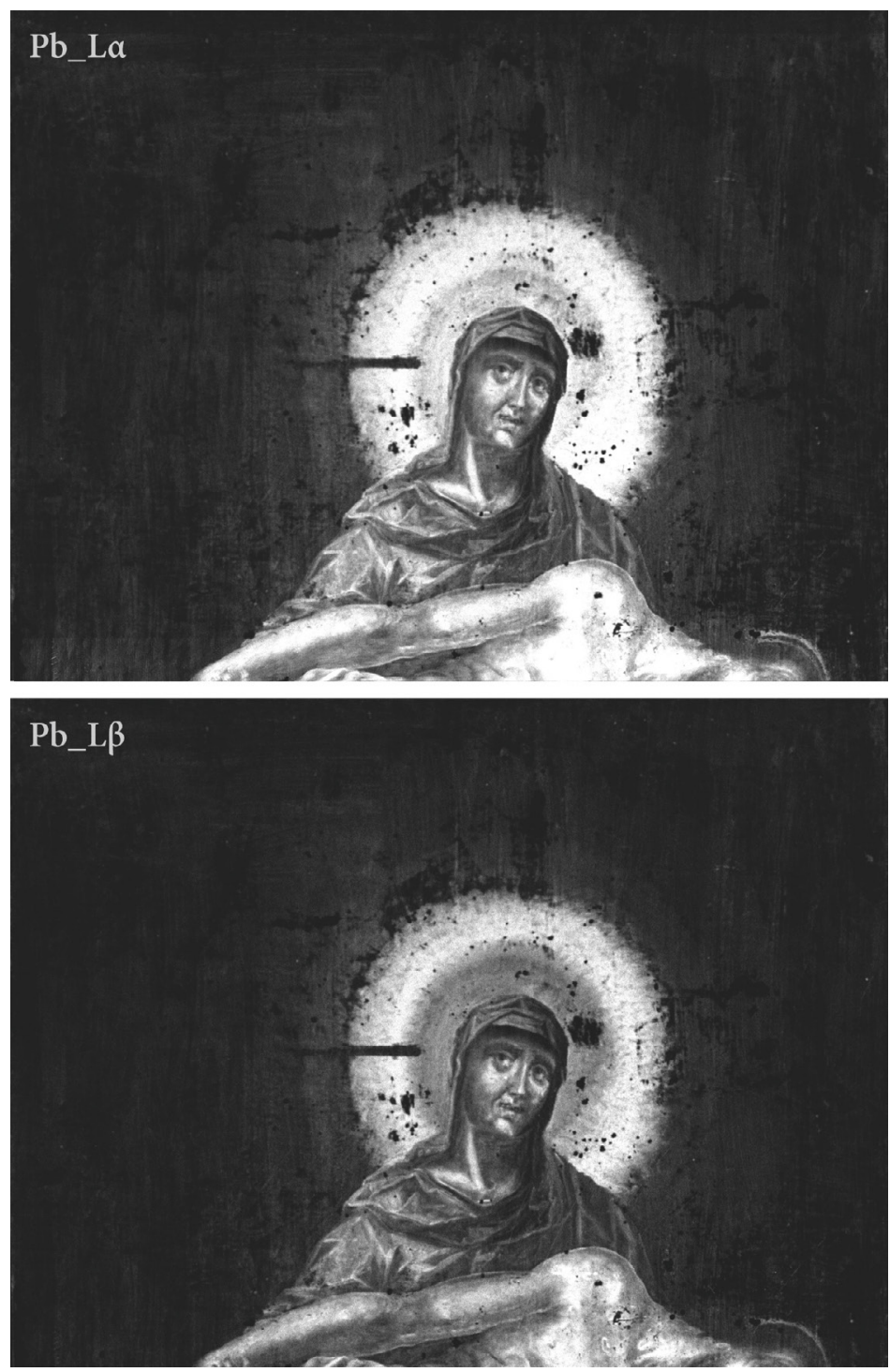

Il. 12. Czarny Potok, kościół pw. św. Marcina Biskupa, Pieta (1649), awers, nimb Marii. MXRF: Pb_L $\alpha, P b \_L \beta$. Fot. M. Goryl 


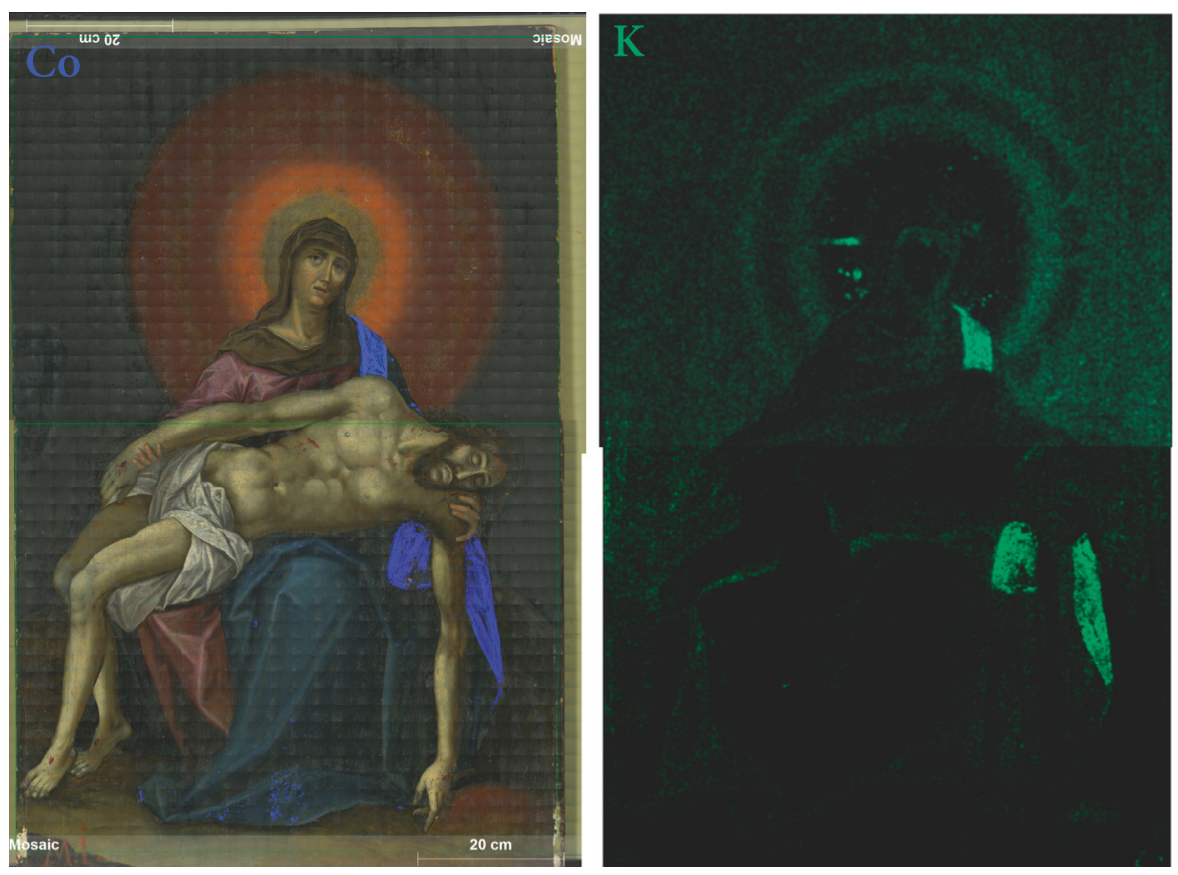

Il. 13. Czarny Potok, kościół pw. św. Marcina Biskupa, Pieta (1649). MXRF awersu: Video Mosaic + rozkład Co i rozkład K. Fot. M. Goryl, oprac. A. Borowska

Pierwiastki charakterystyczne dla smalty, którą namalowano zwisającą z ramienia chustę Marii 


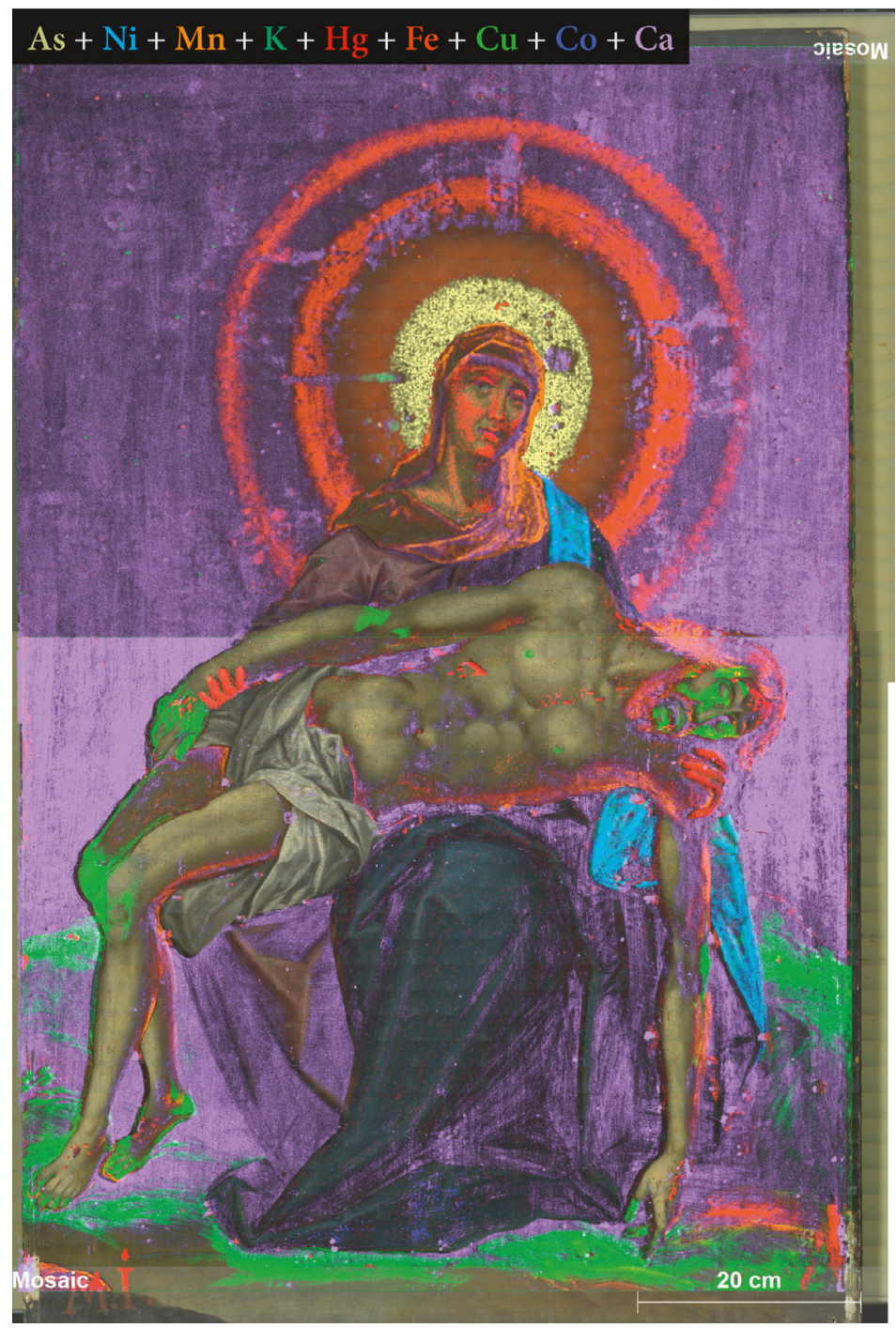

Il. 14. Czarny Potok, kościół pw. św. Marcina Biskupa, Pieta (1649). MXRF awersu: Video Mosaic + rozkład As + Ni $+\mathrm{Mn}+\mathrm{K}+\mathrm{Hg}+\mathrm{Fe}+\mathrm{Cu}+\mathrm{Co}+$ Ca. Fot. M. Goryl, oprac. A. Borowska

Błękitny płaszcz Marii namalowany został drobnoziarnistą ultramaryną. Dla MXRF pigment ten jest „przezroczysty” 


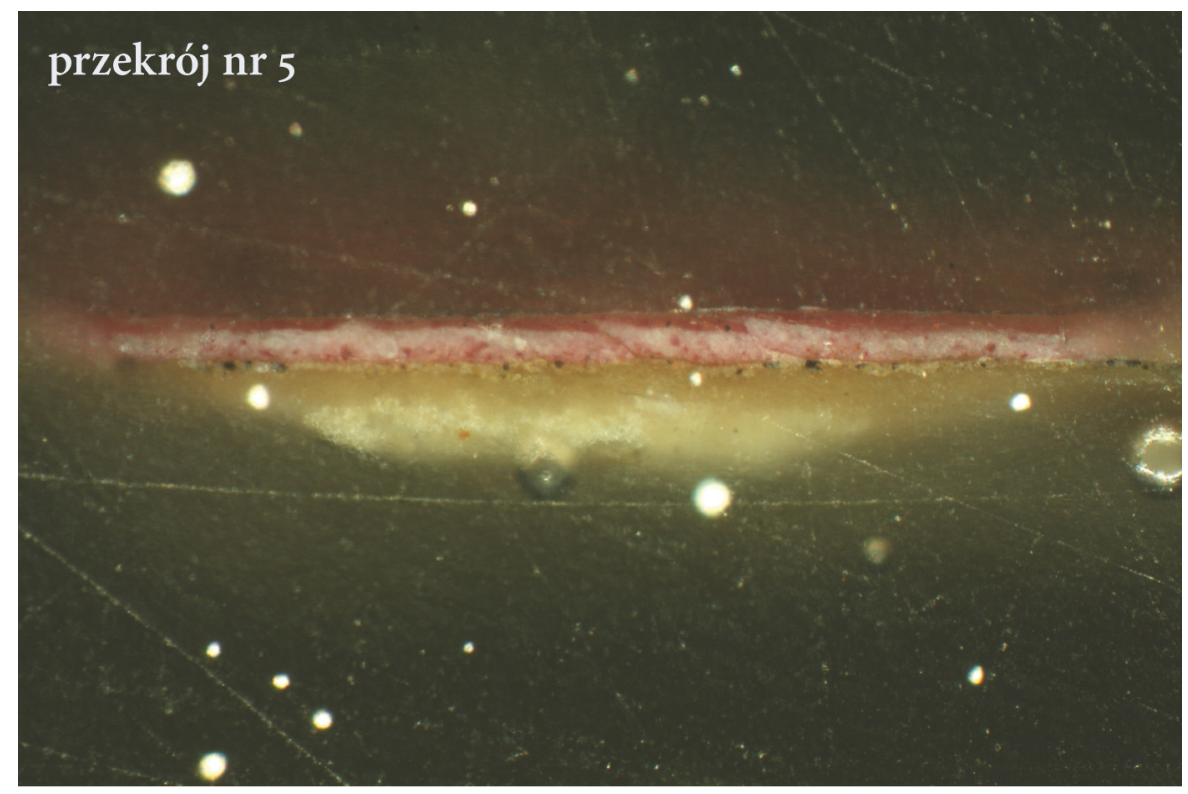

Il. 15. Czarny Potok, kościół pw. św. Marcina Biskupa, Pieta (1649). Przekrój boczny próbki pobranej z partii sukni Marii. Fot. M. Walczak

Modelunek szaty wykonany bielą ołowiową zmieszaną z kraplakiem (spora obecność $\mathrm{Pb}$ ). Górną warstwę stanowi czerwony laserunek organiczny, prawdopodobnie kraplak (w widmie występuje duża ilość $\mathrm{C}$ i Al, a także $\mathrm{Pb}$, pochodzącego najpewniej od sykatywy - analiza 5/1-6) 


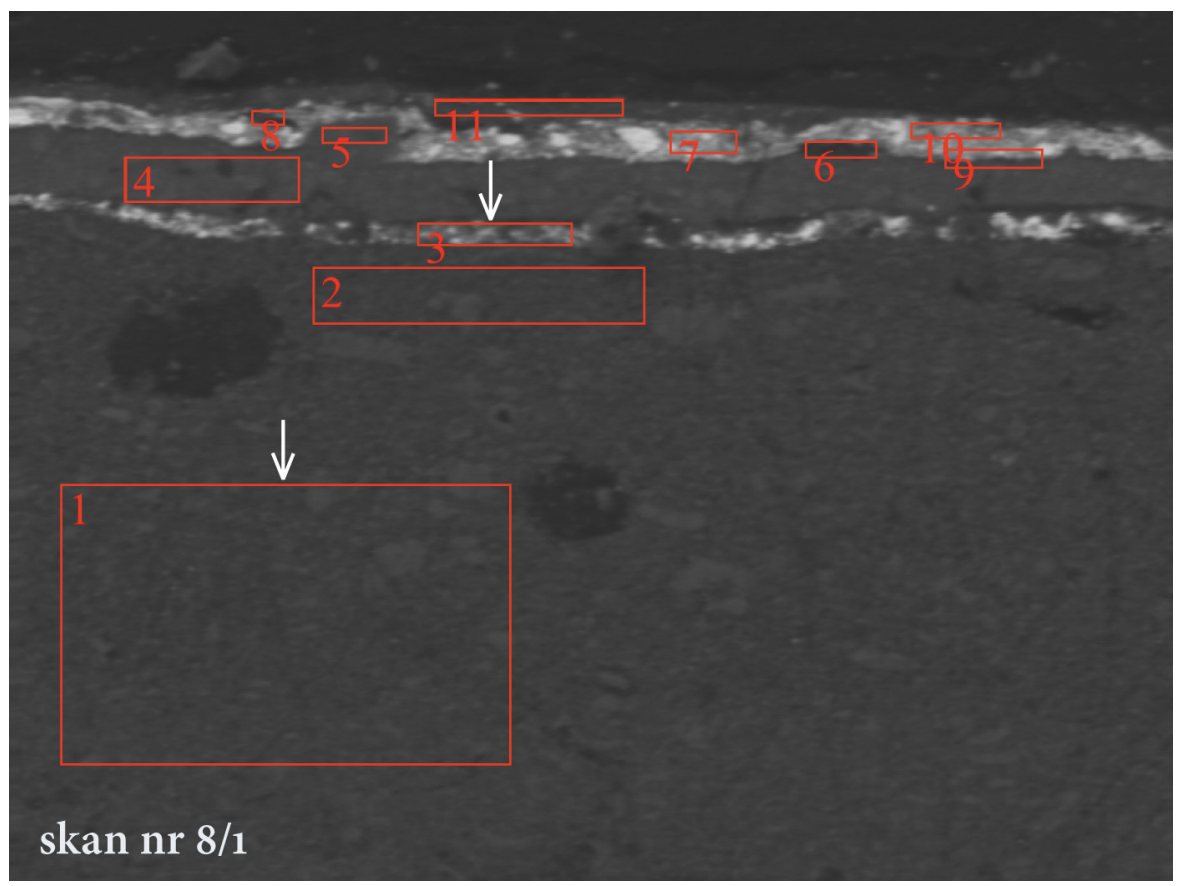

Il. 16. Czarny Potok, kościół pw. św. Marcina Biskupa, Pieta (1649). Skan SEM-EDS przekroju poprzecznego z czarnego tła. Wyk. M. Goryl

Na zaprawie kredowo-klejowej, złożonej z kalcytu (Ca), glinokrzemianów ( $\mathrm{Si}, \mathrm{Al})$, śladowej ilości gipsu (S) i czerni roślinnej (K) (analiza 8/1-1, 8/1-2) leży bardzo dobrze widoczne podmalowanie, będące mieszaniną bieli ołowiowej $(\mathrm{Pb})$, kredy (kalcyt - Ca, glinokrzemian - $\mathrm{Al}$, Si), czerni kostnej $(\mathrm{P})$ i ochry $(\mathrm{Fe})$ (analiza 8/1-3). Na nim znajduje się równo położona warstwa czerni kostnej, prawdopodobnie czarnego bolusu (P, z dodatkiem glinki Al, Si, Mg, Ca) (analiza 8/1-4). Na czerni znaleziono relikty srebra (Ag) (analiza 8/1-5, 8/1-6, 8/1-9). Całość tła pokrywa przemalowanie rozbieloną czernią, z domieszką ochry, pochodzące z poprzednich konserwacji (Ba, Zn, S, Fe) 
ANALYSIS REPORT: IMAGE 3/1-1

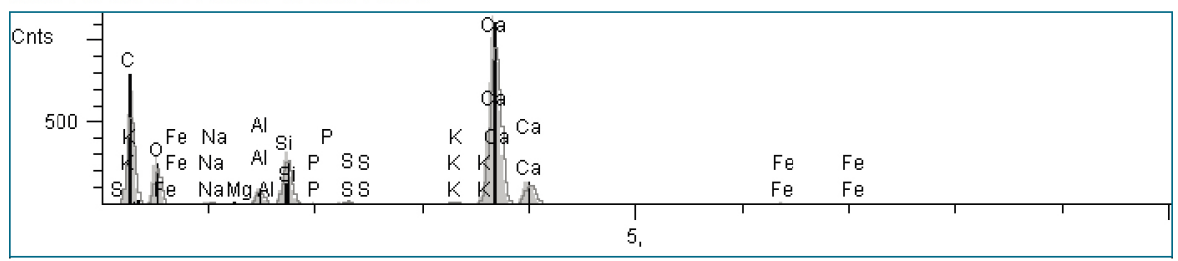

\begin{tabular}{llllll} 
Elt. & Line & Intensity $(\mathrm{c} / \mathrm{s})$ & Error 2-sig & Conc & Units \\
\hline $\mathrm{C}$ & $\mathrm{Ka}$ & 247,68 & 7,038 & 38,232 & wt.\% \\
\hline $\mathrm{O}$ & $\mathrm{Ka}$ & 92,61 & 4,304 & 31,862 & wt.\% \\
\hline $\mathrm{Na}$ & $\mathrm{Ka}$ & 5,37 & $\mathbf{1 , 0 3 6}$ & 0,368 & wt.\% \\
\hline $\mathrm{Mg}$ & $\mathrm{Ka}$ & 4,21 & 0,917 & 0,189 & wt.\% \\
\hline $\mathrm{Al}$ & $\mathrm{Ka}$ & $\mathbf{4 1 , 7 9}$ & $\mathbf{2 , 8 9 1}$ & $\mathbf{1 , 5 4 7}$ & wt.\% \\
\hline $\mathrm{Si}$ & $\mathrm{Ka}$ & $\mathbf{1 4 0 , 4 8}$ & $\mathbf{5 , 3 0 0}$ & $\mathbf{4 , 5 5 1}$ & wt.\% \\
\hline $\mathrm{P}$ & $\mathrm{Ka}$ & $\mathbf{4 , 0 1}$ & $\mathbf{0 , 8 9 5}$ & 0,135 & wt.\% \\
\hline $\mathrm{S}$ & $\mathrm{Ka}$ & $\mathbf{1 1 , 4 3}$ & $\mathbf{1 , 5 1 2}$ & 0,352 & wt.\% \\
\hline $\mathrm{K}$ & $\mathrm{Ka}$ & $\mathbf{1 0 , 3 2}$ & $\mathbf{1 , 4 3 7}$ & 0,330 & wt.\% \\
\hline $\mathrm{Ca}$ & $\mathrm{Ka}$ & $\mathbf{6 1 4 , 5 3}$ & $\mathbf{1 1 , 0 8 6}$ & $\mathbf{2 1 , 9 0 9}$ & wt.\% \\
\hline $\mathrm{Fe}$ & $\mathrm{Ka}$ & 7,27 & $\mathbf{1 , 2 0 6}$ & 0,526 & wt.\% \\
\hline & & & 100,000 & wt.\% & Total \\
\hline
\end{tabular}

kV 20,0; Takeoff Angle 35, $0^{\circ}$; Elapsed Livetime 20,0

Ryc. 1. Analiza składu zaprawy (kreda, glinokrzemiany). Oprac. M. Goryl, A. Borowska 
ANALYSIS REPORT: IMAGE 5/2-1

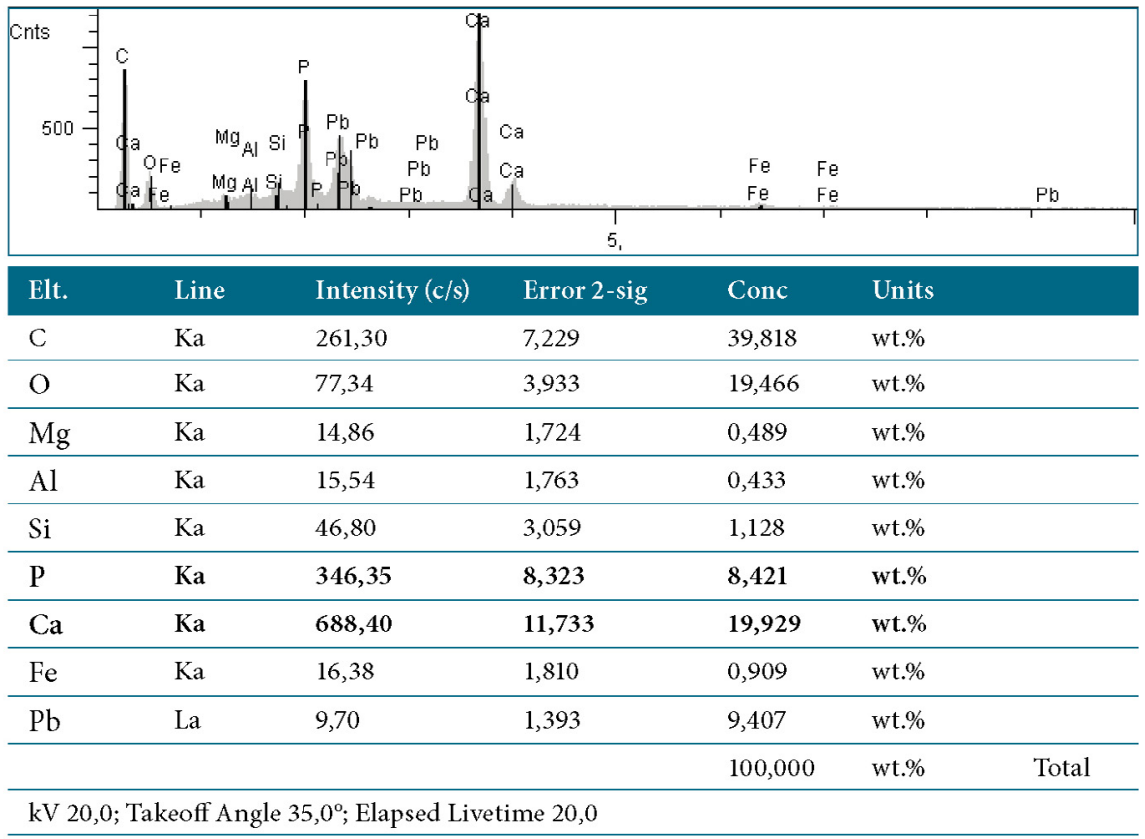

Ryc. 2. Analiza składu imprimitury (czerń kostna). Oprac. M. Goryl, A. Borowska 
ANALYSIS REPORT: IMAGE 8/1-3

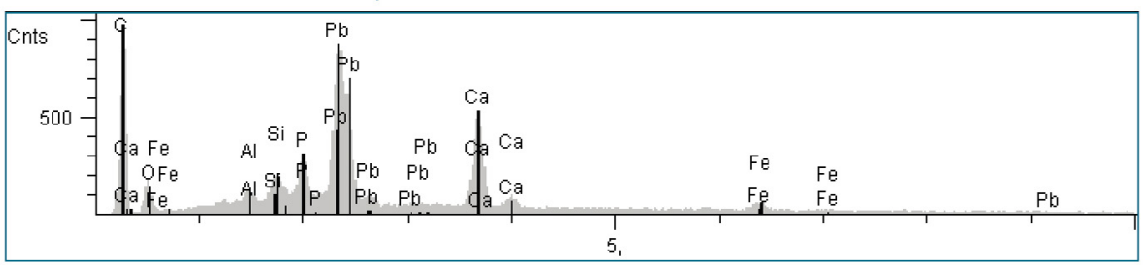

\begin{tabular}{llllll} 
Elt. & Line & Intensity $(\mathrm{c} / \mathrm{s})$ & Error 2-sig & Conc & Units \\
$\mathrm{C}$ & $\mathrm{Ka}$ & 296,05 & 7,695 & 43,105 & wt.\% \\
\hline $\mathrm{O}$ & $\mathrm{Ka}$ & 58,68 & 3,426 & 13,879 & wt.\% \\
\hline $\mathrm{Al}$ & $\mathrm{Ka}$ & 22,08 & 2,101 & 0,732 & wt.\% \\
\hline $\mathrm{Si}$ & $\mathrm{Ka}$ & 60,16 & 3,169 & 1,743 & wt.\% \\
\hline $\mathrm{P}$ & $\mathrm{Ka}$ & $\mathbf{9 5 , 1 7}$ & $\mathbf{4 , 3 6 3}$ & $\mathbf{2 , 7 7 3}$ & wt.\% \\
\hline $\mathrm{Ca}$ & $\mathrm{Ka}$ & $\mathbf{2 8 8 , 1 3}$ & $\mathbf{7 , 5 9 1}$ & $\mathbf{1 0 , 2 5 5}$ & wt.\% \\
\hline $\mathrm{Fe}$ & $\mathrm{Ka}$ & $\mathbf{3 2 , 2 9}$ & $\mathbf{2 , 5 4 1}$ & $\mathbf{2 , 0 5 8}$ & wt.\% \\
\hline $\mathrm{Pb}$ & $\mathrm{La}$ & 23,38 & $\mathbf{2 , 1 6 2}$ & $\mathbf{2 5 , 4 5 6}$ & wt.\% \\
\hline
\end{tabular}

kV 20,0; Takeoff Angle 35, $0^{\circ}$; Elapsed Livetime 20,0

Ryc. 3. Analiza składu imprimitury (biel ołowiowa, kreda, ochra, czerń kostna). Oprac. M. Goryl, A. Borowska 
ANALYSIS REPORT: IMAGE 5/2-3

\begin{tabular}{lllllll}
\hline & \\
\hline
\end{tabular}

kV 20,0; Takeoff Angle 35, $0^{\circ}$; Elapsed Livetime 20,0

Ryc. 4. Analiza składu imprimitury (gips). Oprac. M. Goryl, A. Borowska 
ANALYSIS REPORT: IMAGE 1/4-4

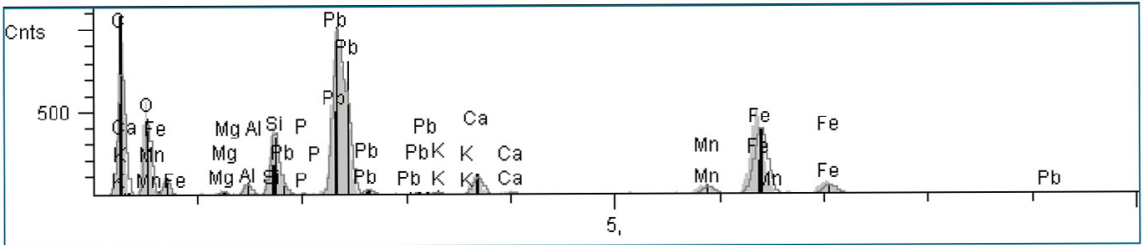

\begin{tabular}{|c|c|c|c|c|c|}
\hline Elt. & Line & Intensity (c/s) & Error 2-sig & Conc & Units \\
\hline $\mathrm{C}$ & $\mathrm{Ka}$ & 228,98 & 5,525 & 31,739 & wt.\% \\
\hline $\mathrm{O}$ & $\mathrm{Ka}$ & 123,77 & 4,062 & 18,051 & wt.\% \\
\hline $\mathrm{Mg}$ & $\mathrm{Ka}$ & 7,76 & 1,017 & 0,287 & wt.\% \\
\hline Al & $\mathrm{Ka}$ & 22,73 & 1,741 & 0,707 & wt.\% \\
\hline $\mathrm{Si}$ & $\mathrm{Ka}$ & 131,16 & 4,182 & 3,507 & wt.\% \\
\hline $\mathrm{P}$ & $\mathrm{Ka}$ & 3,79 & 0,710 & 0,102 & wt. $\%$ \\
\hline $\mathrm{K}$ & $\mathrm{Ka}$ & 4,63 & 0,786 & 0,142 & wt. $\%$ \\
\hline $\mathrm{Ca}$ & $\mathrm{Ka}$ & 44,53 & 2,437 & 1,383 & wt.\% \\
\hline $\mathrm{Mn}$ & $\mathrm{Ka}$ & 22,51 & 1,732 & 1,086 & wt.\% \\
\hline $\mathrm{Fe}$ & $\mathrm{Ka}$ & 209,09 & 5,280 & 11,166 & wt. $\%$ \\
\hline \multirow[t]{2}{*}{$\mathrm{Pb}$} & $\mathrm{Ma}$ & 356,64 & 6,895 & 31,830 & wt.\% \\
\hline & & & & 100,000 & wt. $\%$ \\
\hline
\end{tabular}

kV 20,0; Takeoff $\Lambda$ ngle $35,0^{\circ}$; Elapsed Livetime 20,0

Ryc. 5. Analiza składu rysunku kompozycji (umbra). Oprac. M. Goryl, A. Borowska 
ANALYSIS REPORT: IMAGE 3/2-2

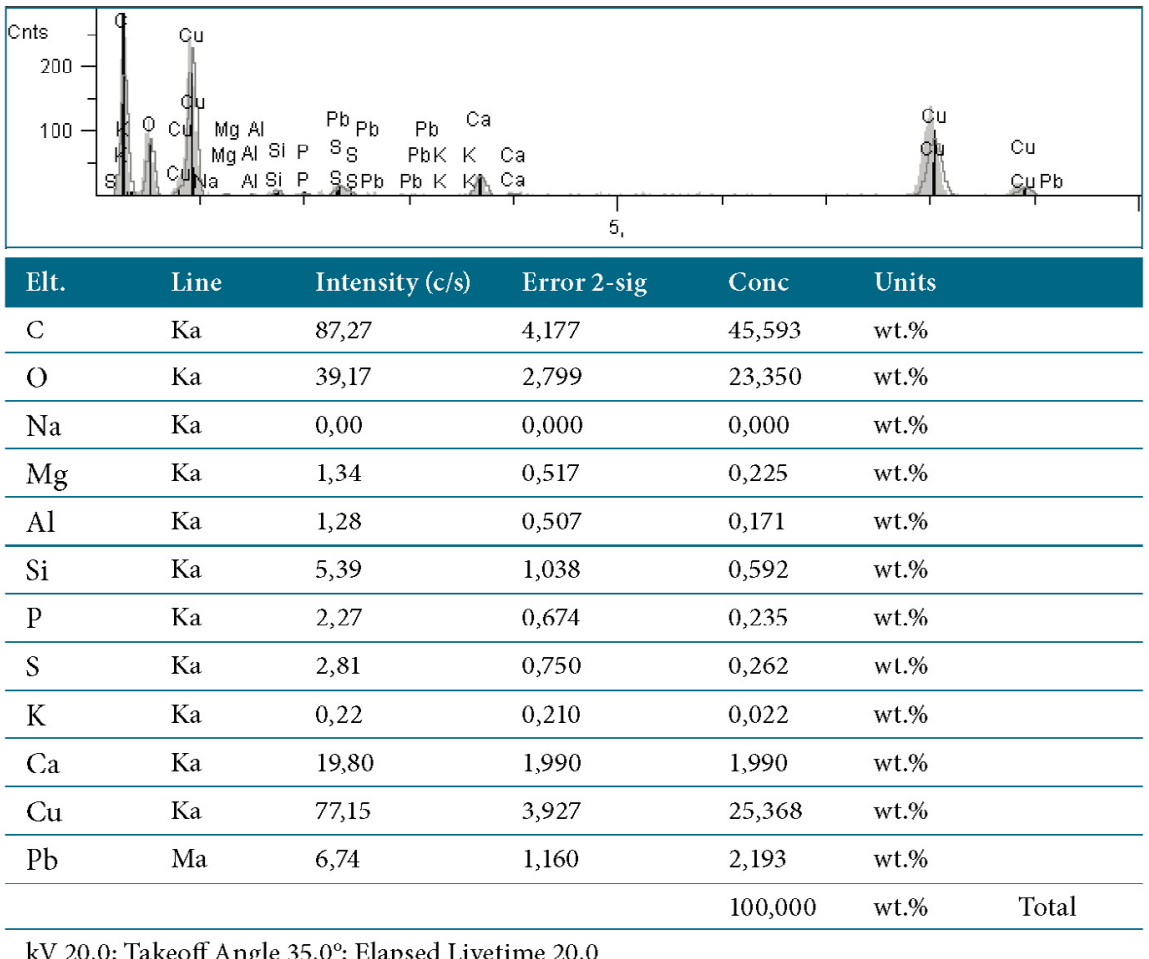

kV 20,0; Takeoff Angle 35, $0^{\circ}$; Elapsed Livetime 20,0

Ryc. 6. Analiza składu warstwy malarskiej krajobrazowego tła (azuryt). Oprac. M. Goryl, A. Borowska 
ANALYSIS REPORT: IMAGE 1/1-5

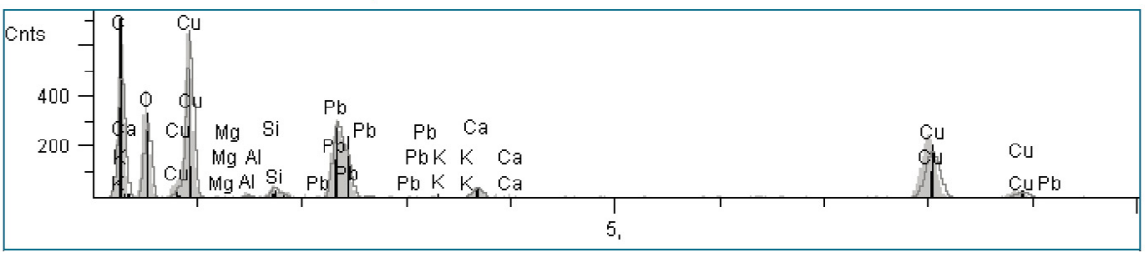

\begin{tabular}{|c|c|c|c|c|c|c|}
\hline Elt. & Line & Intensity (c/s) & Error 2-sig & Conc & Units & \\
\hline C & Ka & 219,95 & 6,632 & 43,175 & wt. $\%$ & \\
\hline $\mathrm{O}$ & $\mathrm{Ka}$ & 128,31 & 5,065 & 28,793 & wt. $\%$ & \\
\hline $\mathrm{Mg}$ & $\mathrm{Ka}$ & 2,93 & 0,766 & 0,191 & wt. $\%$ & \\
\hline $\mathrm{Al}$ & $\mathrm{Ka}$ & 6,64 & 1,152 & 0,344 & wt.\% & \\
\hline $\mathrm{Si}$ & $\mathrm{Ka}$ & 21,16 & 2,057 & 0,915 & wt. $\%$ & \\
\hline $\mathrm{K}$ & $\mathrm{Ka}$ & 3,94 & 0,887 & 0,158 & wt.\% & \\
\hline $\mathrm{Ca}$ & $\mathrm{Ka}$ & 26,30 & 2,293 & 1,079 & wt. $\%$ & \\
\hline $\mathrm{Cu}$ & $\mathrm{Ka}$ & 157,01 & 5,603 & 20,907 & wt. $\%$ & \\
\hline \multirow[t]{2}{*}{$\mathrm{Pb}$} & $\mathrm{La}$ & 3,08 & 0,785 & 4,439 & wt. $\%$ & \\
\hline & & & & 100,000 & wt.\% & Total \\
\hline
\end{tabular}

kV 20,0; Takeoff Angle 35, $0^{\circ}$; Elapsed Livetime 20,0

Ryc. 7. Analiza składu karnacji Chrystusa (azuryt). Oprac. M. Goryl, A. Borowska 
ANALYSIS REPORT: IMAGE 6/3-3

\begin{tabular}{llllllll}
\hline & \\
\hline
\end{tabular}

kV 20,0; Takeoff Angle 35, $0^{\circ}$; Elapsed Livetime 20,0

Ryc. 8. Analiza składu żółtej aureoli na granicy z chustą Marii - warstwa ciemniejsza (aurypigment/realgar). Oprac. M. Goryl, A. Borowska 
ANALYSIS REPORT: IMAGE 6/3-7

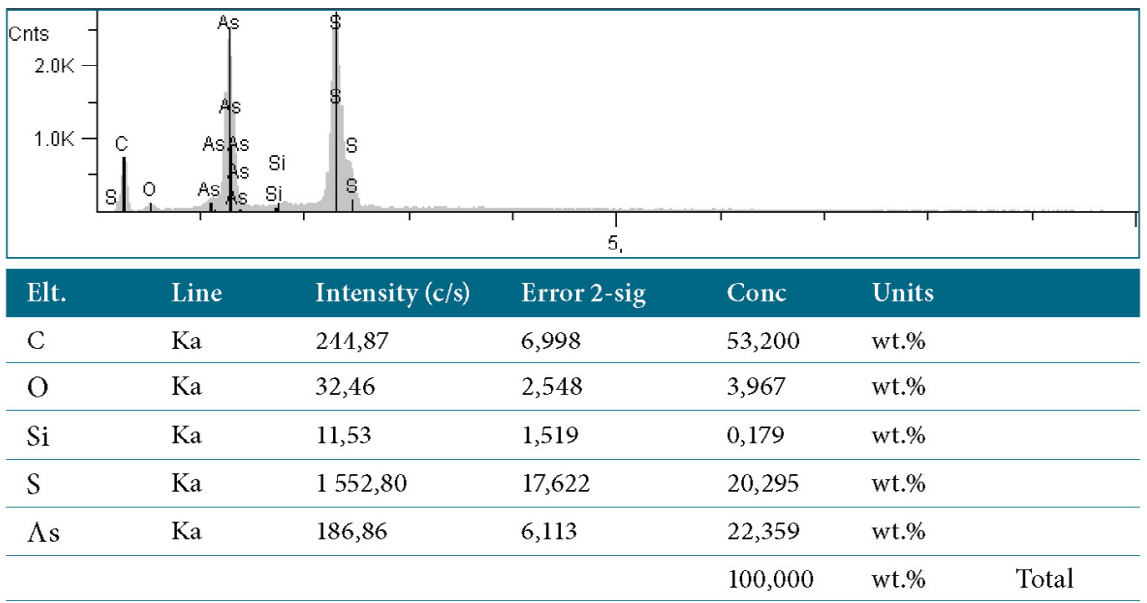

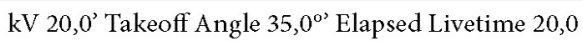

Ryc. 9. Analiza składu żółtej aureoli na granicy z chustą Marii - warstwa jaśniejsza (aurypigment). Oprac. M. Goryl, A. Borowska 


\begin{tabular}{llllllll}
\hline Cnts & & & \\
\end{tabular}

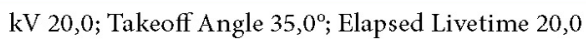

Ryc. 10. Analiza składu chusty Marii (umbra). Oprac. M. Goryl, A. Borowska 


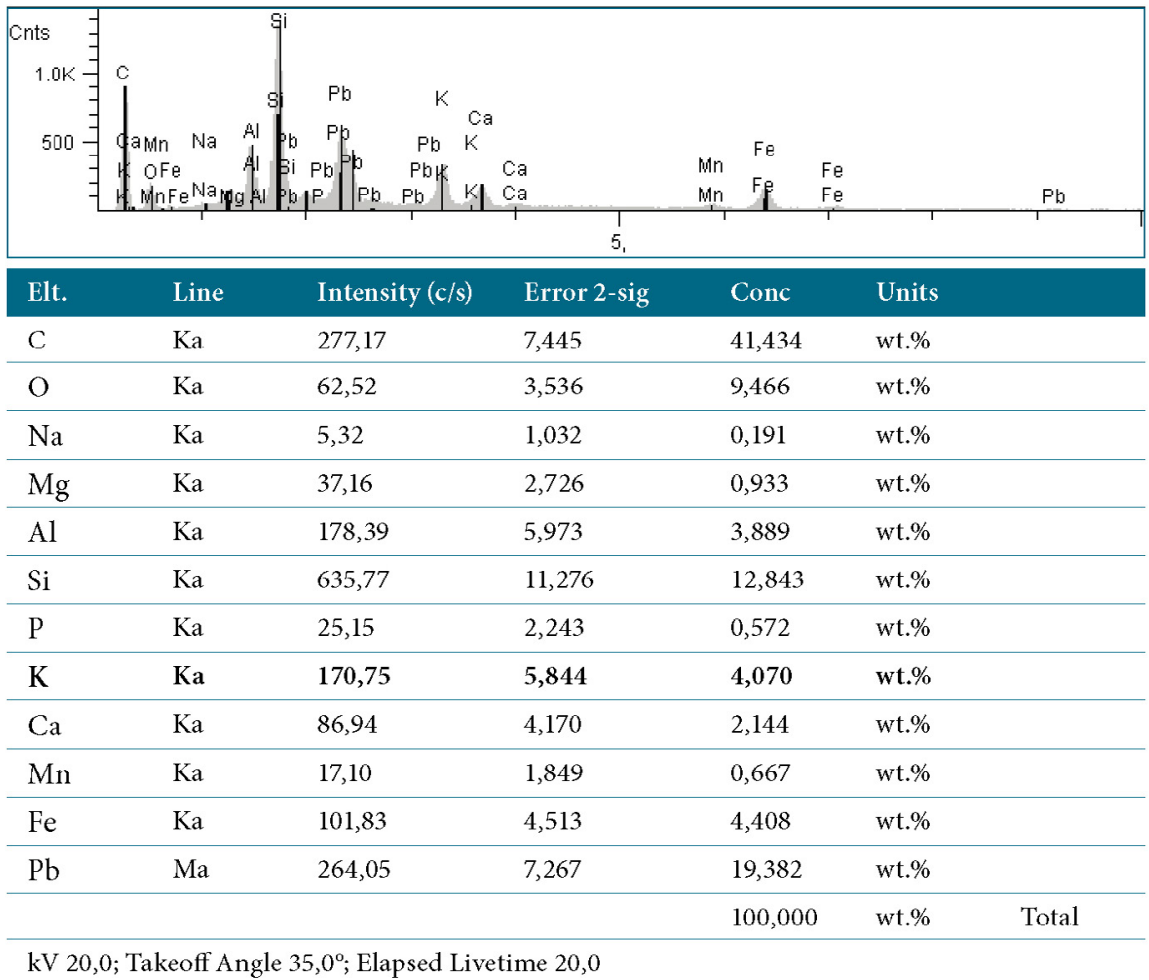

Ryc. 11. Analiza składu chusty Marii (czerń roślinna). Oprac. M. Goryl, A. Borowska 
ANALYSIS REPORT: IMAGE 6/3-11

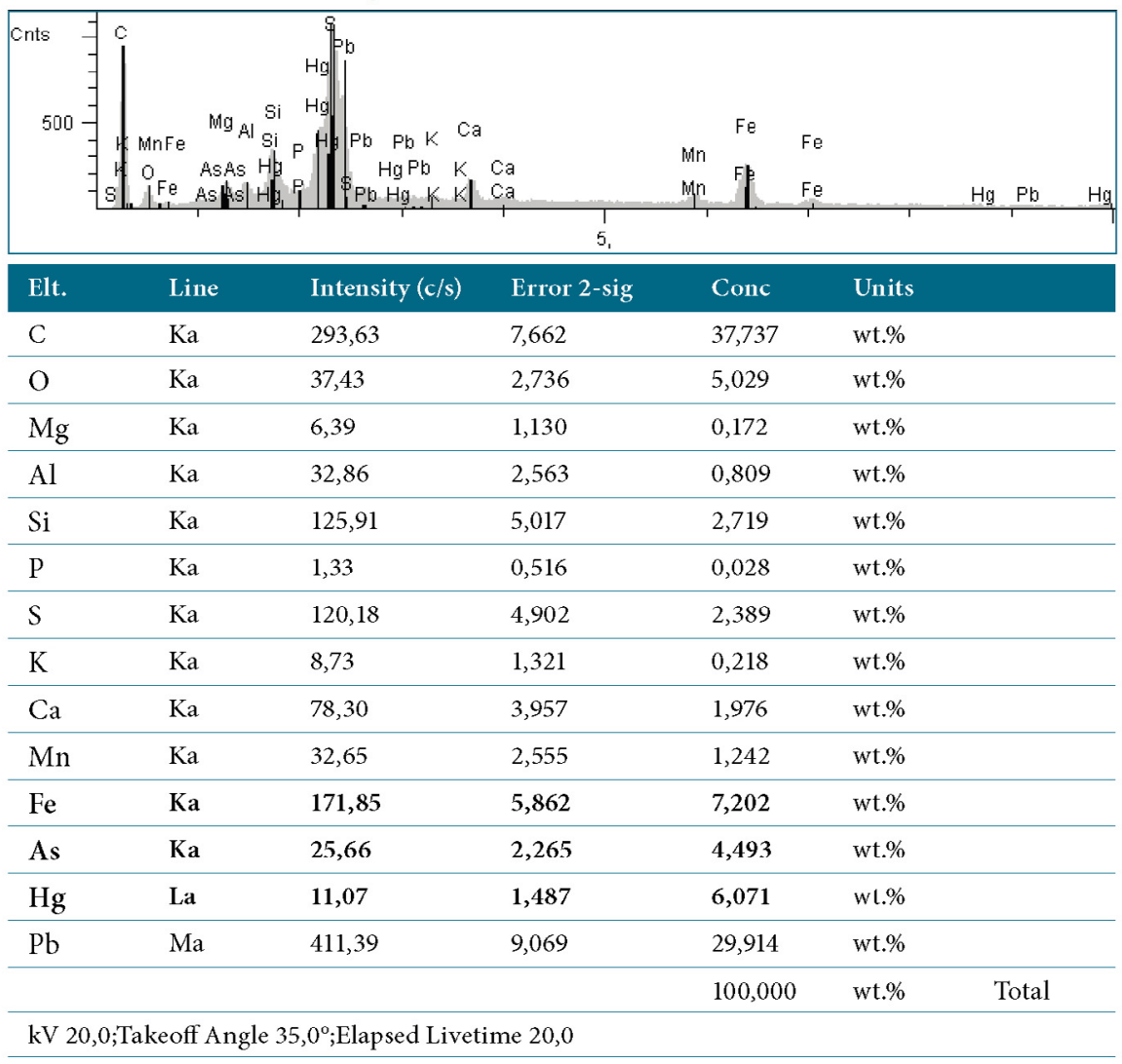

Ryc. 12. Analiza składu chusty Marii (siarczek arsenu, ochra, vermillion). Oprac. M. Goryl, A. Borowska 
ANALYSIS REPORT: IMAGE 2/2-5

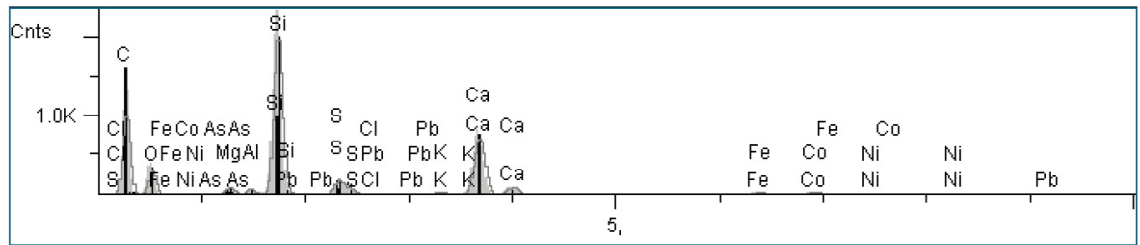

\begin{tabular}{llllll}
\hline Elt. & Line & Intensity $(\mathrm{c} / \mathrm{s})$ & Error 2-sig & Conc & Units \\
$\mathrm{C}$ & $\mathrm{Ka}$ & 234,80 & 4,845 & 51,026 & wt.\% \\
\hline $\mathrm{O}$ & $\mathrm{Ka}$ & 65,56 & 2,560 & 18,288 & wt.\% \\
\hline $\mathrm{Na}$ & $\mathrm{Ka}$ & 1,34 & 0,366 & 0,071 & wt.\% \\
\hline $\mathrm{Mg}$ & $\mathrm{Ka}$ & 10,03 & 1,001 & 0,362 & wt.\% \\
\hline $\mathrm{Al}$ & $\mathrm{Ka}$ & 18,19 & 1,349 & 0,568 & wt.\% \\
\hline $\mathrm{Si}$ & $\mathrm{Ka}$ & 522,63 & 7,229 & 11,632 & wt.\% \\
\hline $\mathrm{Sl}$ & $\mathrm{Ka}$ & 17,95 & 1,340 & 0,540 & wt.\% \\
\hline $\mathrm{Ka}$ & $\mathrm{Ka}$ & 9,39 & 0,449 & 0,064 & wt.\% \\
\hline $\mathrm{Ca}$ & $\mathrm{Ka}$ & 229,98 & 0,969 & 0,305 & wt.\% \\
\hline $\mathrm{Fe}$ & $\mathrm{Ka}$ & 9,26 & 4,795 & 7,753 & wt.\% \\
\hline $\mathrm{Co}$ & $\mathrm{Ka}$ & 11,18 & 0,962 & 0,599 & wt.\% \\
\hline $\mathrm{Ni}$ & $\mathrm{Ka}$ & 3,95 & 1,058 & 0,853 & wt.\% \\
\hline $\mathrm{As}$ & $\mathrm{Ka}$ & 2,60 & 0,629 & 0,342 & wt.\% \\
\hline $\mathrm{Pb}$ & $\mathrm{Ma}$ & 37,02 & 0,510 & 0,750 & wt.\% \\
\hline & & 1,924 & 3,847 & wt.\% \\
\hline $\mathrm{KV}$ & $\mathrm{Kaft}$ & 100,000 & wt.\% \\
\hline
\end{tabular}

kV 20,0; Takeoff Angle 35, $0^{\circ}$; Flapsed Iivetime 20,0

Ryc. 13. Analiza składu fragmentu zwisającej z ramienia chusty Marii (smalta). Oprac. M. Goryl, A. Borowska 
ANALYSIS REPORT: IMAGE 7/3-1

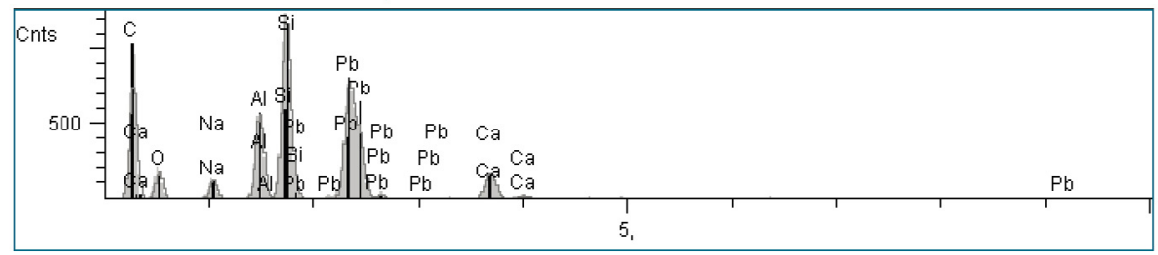

\begin{tabular}{llllll} 
Elt. & Line & Intensity $(\mathrm{c} / \mathrm{s})$ & Error 2-sig & Conc & Units \\
$\mathrm{C}$ & $\mathrm{Ka}$ & 342,94 & 8,281 & 41,977 & wt.\% \\
\hline $\mathrm{O}$ & $\mathrm{Ka}$ & 76,84 & 3,920 & 9,661 & wt.\% \\
\hline $\mathrm{Na}$ & $\mathrm{Ka}$ & 57,88 & 3,402 & 1,723 & wt.\% \\
\hline $\mathrm{Al}$ & $\mathrm{Ka}$ & 280,88 & 7,494 & 5,288 & wt.\% \\
\hline $\mathrm{Si}$ & $\mathrm{Ka}$ & 620,00 & 11,135 & 11,039 & wt.\% \\
\hline $\mathrm{Ca}$ & $\mathrm{Ka}$ & 111,30 & 4,718 & 2,432 & wt.\% \\
\hline $\mathrm{Pb}$ & $\mathrm{Ma}$ & 421,30 & 9,179 & 27,880 & wt.\% \\
\hline
\end{tabular}

kV 20,0; Takeoff Angle 35, $0^{\circ}$; Elapsed Livetime 20,0

Ryc. 14. Analiza składu płaszcza na kolanach Marii (ultramaryna). Oprac. M. Goryl, A. Borowska 
ANAI,YSIS REPORT: IMAGE 5/1-6

\begin{tabular}{llllllll}
\hline Cnts & & & \\
&
\end{tabular}

Ryc. 15. Analiza składu sukni Marii (laserunek kraplakiem). Oprac. M. Goryl, A. Borowska 
ANALYSIS REPORT: IMAGE 8/1-4

\begin{tabular}{lllllll}
\hline & \\
\hline
\end{tabular}

Ryc. 16. Analiza składu najstarszej czarnej warstwy w tle (czarny bolus). Oprac. M. Goryl, A. Borowska 
ANALYSIS REPORT: IMAGE, 8/1-9

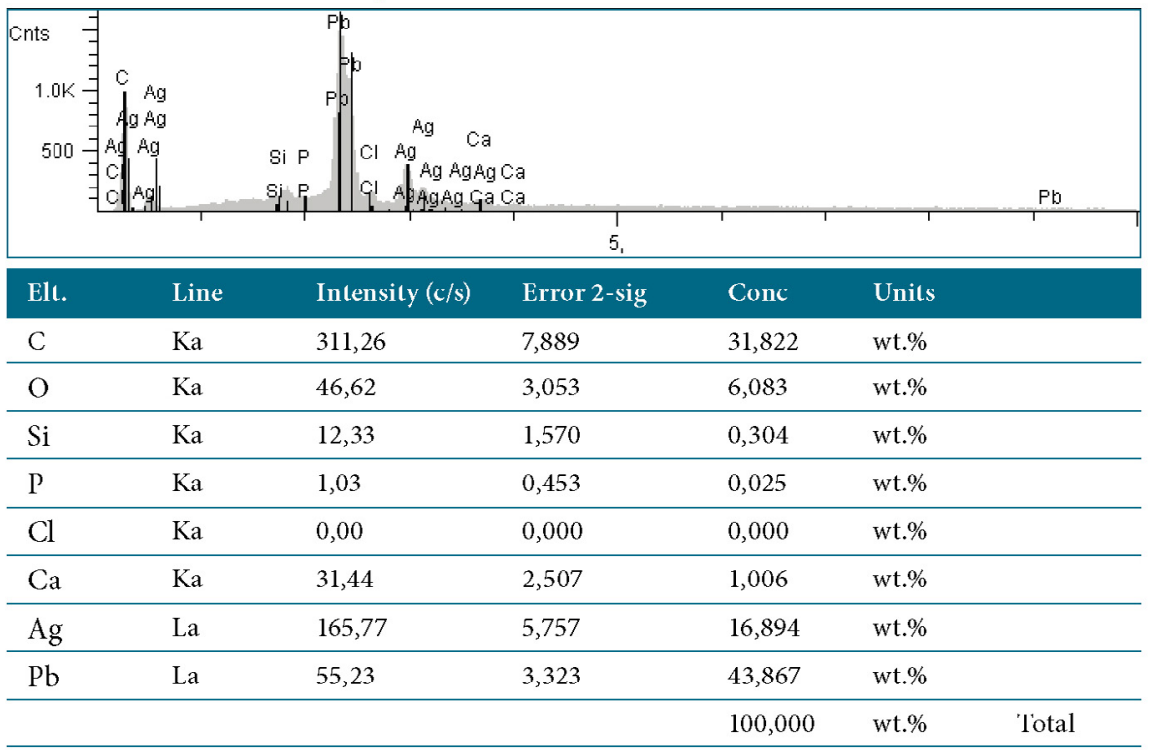

kV 20,0; Takeoff Angle 35, $0^{\circ}$; Elapsed Livetime 20,0

Ryc. 17. Analiza składu warstwy tła pod przemalowaniami (srebro). Oprac. M. Goryl, A. Borowska 


\section{Bibliografia}

\section{Źródła}

Czarny Potok, Archiwum Parafialne:

b. sygn., Gutta Maris gratianum Mariae Etiam In Nigram Vallem Copioso Stillamine Cadens. Łaski Cudowne Skarby Pociech rozmaitych dobrodzieystwa prawie codzienne: od Nayboleśnieyszey Matki Jezusowey Przenayświentszey Maryi Panny w Obrazie iey Czarnopotockim doznane y odebrane. A przez Xiędza Tomasza Franciszka Włoszkiewicza Plebana Czarnopotockiego w fascuł zebrane y zkompendyowane Roku Pańskiego 1727.

b. sygn., [Kronika parafialna] Liber Memorabilium ad Ecclesia Parochiali Czarnopotocensi et de iis quae in ea gesta sunt et evenire, in parennem memoriam.

b. sygn., Zbiór łask cudownych doznanych od Najboleśniejszej Matki Jezusowej Przenajświętszej Maryi Panny w obrazie Jej łaskami słynącym w Czarnym Potoku. Zebrane przez ks. Zygmunta Miętusa.

Kraków, Archiwum Kurii Metropolitalnej w Krakowie (AKMK), Akta wizytacji kapitulnych (AWK):

AVCap 5/1596/, Acta visitationis exterioris decanatuum Boboviensis, Sandecensis et Novi Fori ad archidiaconatum Sandecensem pertinentium per Christophorum Kazimirski a. 1596 expeditae.

AVCap 25/1608/, Visitatio decanatus Sandecensis et Novi Fori externa per Joannem Januszowski a. 1608 expedita.

AVCap 60/1728/, Visitatio interna et externa Officialatus Sandecensis per Josephum de Zakliczyn Jordan a. 1723-1728 peracta.

Kraków, Archiwum Narodowe w Krakowie, Akta Miasta Krakowa:

29/33/0/1.21/1427, Cathalogus civium Cracoviensium secundi ordinis..., daty: 1634-1668, skan 34/100. Dostęp 26.07.2021. https://www.szukajwarchiwach.gov. pl/jednostka/-/jednostka/5638751?_Jednostka_delta=20\&_Jednostka_resetCur=false\&_Jednostka_cur=3; dostęp 26.07.2021.

Łącko, Archiwum Parafialne:

b. sygn., Liber visitationum in decanatu Łącensi confectus a. 1793 et 1794 per Michaelem Skoczniowski dec. For. Łącensem.

Wrocław, Biblioteka Zakładu Narodowego im. Ossolińskich:

1871/I, Relatio fundationis conventus visnicensis Salvatoris Carmelitarum Discalceatorum cum annalibus ejusdem monasterii 1624-1719.

\section{Opracowania}

Biblia Tysiaclecia. Poznań: Pallotinum, 2003.

Długosz, Jan. Liber beneficiorum Dioecesis Cracoviensis. W Jan Długosz. Opera omnia, t. 8, wyd. A[ndrzej] Przezdziecki. Cracoviae: Ex typographia Kirchmaieriana, 1863-1864. 
Downey, Erin Elizabeth. „The Bentveughels: Networking and Agency in the Seicento Roman Art Market.” Rozprawa doktorska, Temple University, 2015. http://www. digital.library.temple.edu.

Fridrich, Alojzy. Historie cudownych obrazów Najświętszej Maryi Panny w Polsce. T. 2. Kraków: Wydawnictwo Towarzystwa Jezusowego, 1904.

Gadomski, Jerzy. Gotyckie malarstwo tablicowe Małopolski. Warszawa: PWN, 1981.

Gadomski, Jerzy. „Malarstwo tablicowe w Małopolsce.” W Malarstwo gotyckie w Polsce, t. 1, red. Adam S. Labuda i Krystyna Secomska, 251-305. Warszawa: Wydawnictwo DiG, 2004.

Gadomski, Jerzy. „Związki Mistrza ‘Opłakiwania’ z Chomranic z twórczością Roberta Campin.” Sprawozdania z Posiedzeń Komisji Naukowych Oddziału PAN w Krakowie 15, z. 1 (1971): 143-145.

Gąsior, Anna, Piotr Łabuda, i Janusz Królikowski. Współczująca Matka. Z historii Sanktuarium Matki Bożej Bolesnej w Czarnym Potoku. Tarnów: Wydawnictwo Diecezji Tarnowskiej Biblos, 2008.

Jaskowski, Zbigniew. „Dokumentacja techniczno-robocza z konserwacji obrazu na desce 'Pieta', r. 1971.” Dokumentacja konserwatorska, Kraków 1971, Archiwum Wojewódzkiego Urzędu Ochrony Zabytków w Nowym Sączu, nr inw. 85.

Kraińska, Elżbieta. „Materiały archiwalne do historii małopolskiego malarstwa renesansowego (1500-1650).” Folia Historiae Artium 7 (1965): 97-116.

Kraińska, Elżbieta. „Materiały źródłowe do malarstwa renesansowego w Małopolsce historycznej (1500-1650).” Sprawozdania z Posiedzeń Komisji PAN 1 (1962): 204-207.

Kumor, Bolesław. „Archidiakonat sądecki. Opracowanie tekstów źródłowych do atlasu historycznego Kościoła w Polsce.” Archiwa, Biblioteki i Muzea Kościelne 8 (1964): 271-304.

Łopatkiewicz, Piotr, i Tadeusz Łopatkiewicz. Stanisława Tomkowicza Inwentarz zabytków powiatu sądeckiego. Kraków: Wydawnictwo MNK, 2007.

Mamak, Piotr. Kult Matki Boskiej Bolesnej w Czarnym Potoku. Tuchów: Mała Poligrafia Redemptorystów, 1999.

Mander, Karel van. Het schilder-boeck (facsimile van de eerste uitgave, Haarlem 1604). Davaco Publishers: Utrecht 1969. Dostęp 23 kwietnia 2021. http://www.dbnl.org/ tekst/mand001schi01_01/colofon.htm.

Michalczyk, Zygmunt. W lustrzanym odbiciu. Grafika europejska a malarstwo w Rzeczypospolitej w czasach nowożytnych ze szczególnym uwzględnieniem późnego baroku. Warszawa: Instytut Sztuki PAN, 2016.

Myara Kelif, Élinor. 'Flemish Artists' Training Voyages in Italy'. Encyclopédie pour une histoire numérique de l'Europe. Dostęp 20 kwietnia 2021. https://ehne.fr/en/ node/12514.

Osolińska, Agata. „Dokumentacja prac konserwatorskich ołtarza głównego kościoła w Czarnym Potoku.” Dokumentacja konserwatorska, 1999, Archiwum Wojewódzkiego Urzędu Ochrony Zabytków w Nowym Sączu, nr inw. 5065. 
Pielas, Magdalena. Matka Boska Bolesna. Kraków: Universitas, 2000.

Pulit, Franciszek. „Historia obrazów - ‘Opłakiwania Chrystusa’ i ‘Matki Boskiej Bolesnej’ w Czarnym Potoku.” Rocznik Sądecki 28 (2000): 33-47.

Rzepińska, Maria. Historia koloru $w$ dziejach malarstwa europejskiego. T. 1. Warszawa: Arkady, 1989: 131-132.

Słownik artystów polskich i obcych $w$ Polsce działających. T. 3. Red. Jolanta Maurin-Białostocka i Janusz Derwojed. Zespół red. Hanna Bartnicka-Górska et al. Współpraca Maria Bardini et al. Wrocław-Warszawa-Kraków-Gdańsk: Zakład Narodowy im. Ossolińskich / Wydawnictwo Polskiej Akademii Nauk, 1979.

Szczerbak, Władysław. Sanktuarium Matki Boskiej Bolesnej w Czarnym Potoku. Studium historyczno-ikonograficzne. Tarnów: Mała Poligrafia Redemptorystów w Tuchowie, 1999.

Szlezynger, Piotr S. Dawny kościół Karmelitów Bosych w Wiśniczu. Bochnia-Nowy Wiśnicz: Stowarzyszenie Bochniaków i Miłośników Ziemi Bocheńskiej / Towarzystwo Miłośników Wiśnicza, 2009.

Tomkowicz, Stanisław. Przyczynki do historyi kultury Krakowa w pierwszej poł. XVII w. Lwów: Nakładem Towarzystwa dla Popierania Nauki Polskiej, 1912.

Tomkiewicz, Władysław. Z dziejów polskiego mecenatu artystycznego w wieku XVII. Wrocław: Wyd. Zakładu Narodowego im. Ossolińskich, 1952.

Walicki, Michał. Malarstwo polskie: gotyk, renesans, wczesny manieryzm. Warszawa: Auriga / Oficyna Wydawnicza w Warszawie, 1961.

Wanat, Benginus Józef, OCD. „Architektura i wyposażenie kościoła i klasztoru Karmelitów Bosych w Wiśniczu.” Folia Historica Cracoviensia 19 (2013): 119-132.

Wpis do rejestru zabytków nr B-129-3V z dnia 13.02.1970 r., mps, Archiwum Małopolskiego Wojewódzkiego Konserwatora Zabytków, Delegatura w Nowym Sączu.

Żaki, Andrzej. „Wyniki wstępnych badań grodziska w Naszowicach, powiat Nowy Sącz.” Wiadomości Archeologiczne 3 (1954): 234-251. 